Historic, Archive Document

Do not assume content reflects current scientific knowledge, policies, or practices. 

2,29

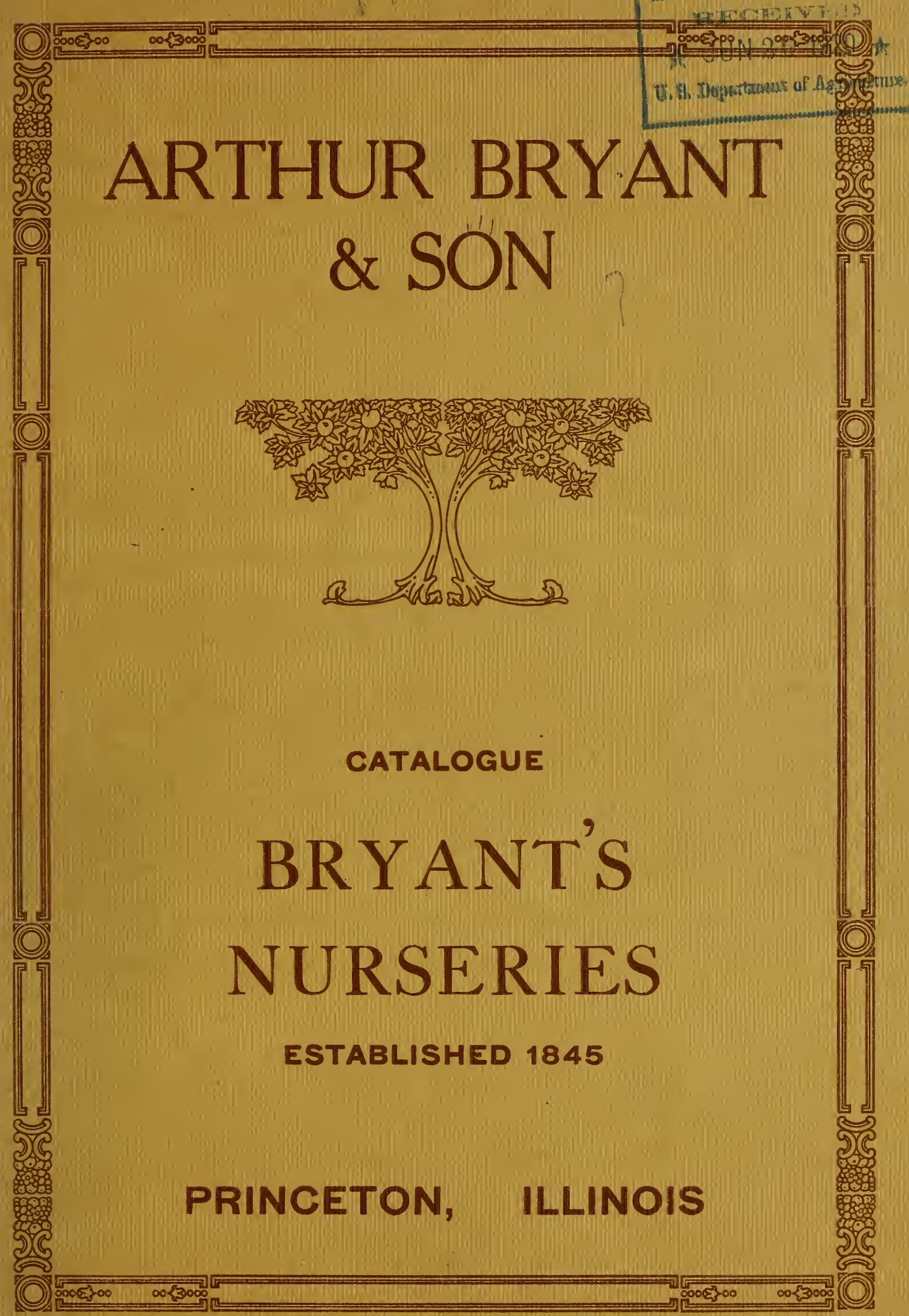





\section{By Way of Introduction}

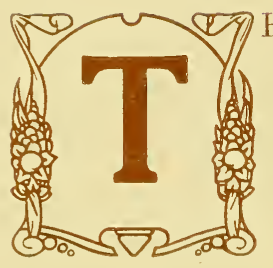

HE Bryant Nurseries are the oldest Nurseries now doing business in the State of Illinois. Established in $18+5$ by that pioneer horticulturist, Arthur Bryant, Senior, it has for more than seventy two years been carried on by father and son until it is now in the hands of the third and fourth generations. The late Arthur Bryant had, at the time of his death in May, 1907, been actively connected with the business for more than fifty years.

From the start the business has increased gradually and its scope has broadened until it now stands without exception as the largest general Nursery in Illinois. For a business house to live for over seventy years is something, but to have it grow from small beginnings to the present large volume of business which reaches into nearly every state and supplies its products to thousands of pleased customers each season, is much more. Seventy years of achievement in any line of business shows that thought and care have been given to the most minute details and that a policy of honesty and fair dealing has been strictly adhered to-otherwise seventy years of continued growth would have been impossible.

Some three hundred and seventy five acres of fertile, well tilled, heavily manured land are used in the business; of this amount about two hundred and fifty acres are in nursery stock each growing season. The main nursery, including the office and packing grounds, is located just south of the limits of the city of Princeton. Electric cars on the Chicago, Ottawa, and Peoria Railroad stop directly in front of the office. Visitors are always welcome; we are always glad to show you through our plantings and packing houses.

\section{GENERAL REMARKS.}

rvices.-All of the prices in this catalog: include packing and delivery by freight at the purchaser's railroad station without additional charge.

Shipping Season.-Our Spring shipping season opens about the first of March and lasts until about the middle of May. The Fall season lasts from about the first of October until about the first of December.

Shipping Facilities.-We are located on the main line of the Burlington Railroad 104 miles from Chicago. We also have direct connection with the main line of the Rock Island Railroad via DePue, Ill., over the Chicago, Ottawa, and Peoria Railroad, an electric line. Two Express Companies, the Adams and the Wells-Fargo, give excellent service.

Grade.-Our stock will not be coarse or overgrown, but carefully selected, well graded, and first class in every way.

Inspection.-Our Nurseries are regularly inspected by the State Entomologist's Office and a certificate of inspection will accompany each shipment. 


\section{A Few Hints on Transplanting}

When to Plant.-Deciduous trees, shrubs and vines can be planted either in the Spring or in the Fall. Hardy herbaceous perennials are best transplanted in the Fall, tho they may very well be transplanted in the Spring. The best time to transplant evergreens is in the late Spring, tho they can be very successfully moved during the latter part of August and September.

Care of Stock on Arrival--Success with nursery stock depends in a large measure upon its care after arrival. The natural place for the roots is in the ground, and as soon as the stock arrives it should be unpacked and either planted at once or "heeled in" so that mellow earth will come in contact with the roots. Always remember that an hours exposure to wind or hot sun is sure death to many plants. Especially is this the case with evergreens-when once the roots are dry no amount of soaking will restore them to their natural condition.

Successful Planting.-In all cases success in planting depends largely, upon four things:

1. The selection of a plant of a kind adapted to the climate, soil and location in which it is to be placed.

2. On planting at a time when the stock is in a dormant condition.

3. The use of nursery-grown stock rather than collected stock. Nursery-grown stock has been previously transplanted and as a result is well supplied with fiberous feeding roots close to the trunk to nourish and sustain it after planting.

4. The taking of proper care of the plants until they have become thoroughly established in their new location.

Soil-Generally speaking, deciduous plants will thrive in almost any good garden soil. Fertilizer, in the form of compost or manure, is beneficial tho not essential. Care should always be taken in using fresh manure to see that none of the manure comes in direct contact with the roots. Areas that have been but recently graded are apt to be void of fertile top soils and unless such soil is provided the stock cannot be expected to make a good vigorous growth.

Pruning.-In removing a tree from the ground, no matter how carefully this may be done, some of the roots will be broken or destroyed. To restore the proper balance between the top and the root system, and also to properly train the head, it will often be necessary to cut the top back quite heavily. Also all cut, broken, or bruised roots should be cut to new sharp surfaces before the plant is set in the ground.

Planting.- In planting, be sure to dig the holes large enough to allow the roots to spread out in their natural position and deep enough that the plant may set about an inch deeper in the ground than it originally did. Do not dig the holes so long before the stock is to be planted that the soil will have a chance to dry out. Work the dirt in between the roots and pack it around them well. When the ground is very dry, puddle the dirt well before the hole is entirely filled.

Care After Planting.-Grass should not be allowed to grow close up to plants that have just been set, as it will stunt their growth. The ground about them should be kept clean and loose and a heavy dust mulch kept to preserve the moisture.

Watering.-If a severe drought follows the planting, artificial watering should be resorted to. This does not mean a frequent sprinkling of the ground about the plant, but a thorough soaking once or twice a week when the ground is dry. Do not water a plant while the sun is shining on it-evening is the best time to do all watering.
IVhat to Plant.-Every planting, no matter how small, appears better if it is planted to a plan, and an operation of any size at all is practically impossible without one. Of course a well grown plant is always attractive, but unless properly placed in relation to the other plants with which it is associated, it lacks the effectiveness of an artistic setting. Too many places are "just planted." The result is a jumble of misplaced things which only accentuates the owner's lack of forethought.

We shall be very glad to supplement the descriptions given in this booklet with more specific advice as to what. how, and when to plant. We maintain a Service Department which is especially equipped for this purpose, and they will gladly help you with your landscape plans or tell you what varieties of fruits will give you the best satisfaction. 


\section{Planting Tables}

\section{SUITABLE DISTANCES FOR} PLANTING.

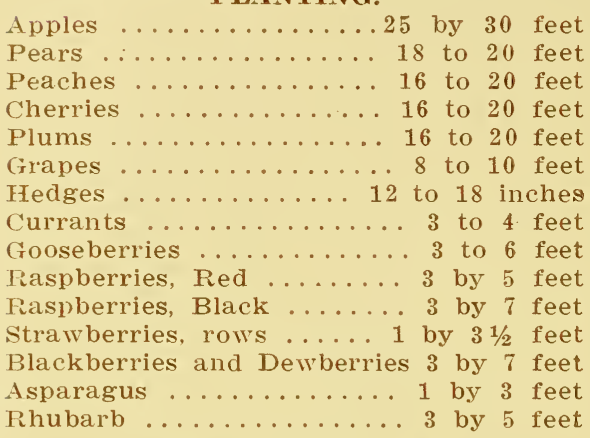

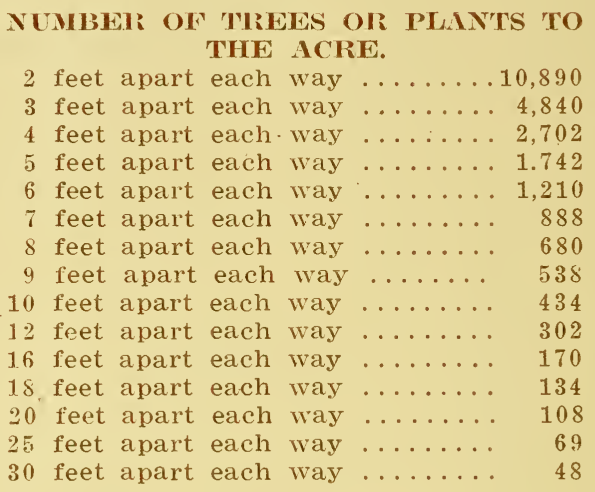

Rule.-Multiply the distance in feet between the rows by the distance the plants are apart in the rows and the product will be the number of square feet occupied by each plant or hill, which, divided into the number of square feet in an acre $(43,560)$, will give the number of plants to the acre.

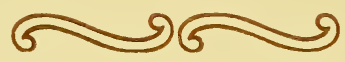

\section{CONTENTS}

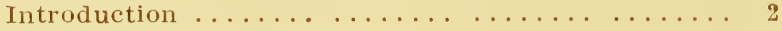

Hints on Transplanting ............... 3

Fruit Department ................. 5

Ornamental Department .............. 11

Deciduous Trees ........................ 11

Evergreens $\ldots \ldots \ldots \ldots \ldots \ldots \ldots \ldots \ldots \ldots$

Deciduous Shrubs ...................... 17

Roses ......................... . . 22

Hedge Plants .................... 26

Ornamental Vines ................. 27

Hardy Herbaceous Perennials . . . . . . . . . 29

Index $\ldots \ldots \ldots \ldots \ldots \ldots \ldots \ldots \ldots$ 


\section{Fruit Department}

The varieties of fruit trees which we list in this department are those which we can particularly recommend for this section of the country-varieties which experience shows will bear the finest fruit and the most of it. The newer varieties which we list we have tested and found good, and we can very well say that those sorts which we offer here are the best of the older sorts and the cream of the new varieties.

\section{APPLES}

The Apple is, without a doubt, the most important fruit tree grown in this country. Unlike other fruits, its period of ripening extends well throughout the year, and by a judicious selection of varieties an almost constant succession can be obtained. The tree thrives in a variety of soils, any soil that will produce a good yield of wheat or corn being a good soil for apples, but it is most productive and its tendency torrard Inngevity is greatest when planted in a deep, fertile loam.

In order to secure thorough pollenation, which is necessary if one wishes a full crop, it is well in setting out large orchards not to plant large blocks of any one variety, but to change the variety every three or four rows.

50 cents each: $\$ 1.00$ per 10: $\$ 30.00$ per 100.

\section{SUMMER VARIETHES.}

Yellow Transparent. Tree very hardy, succeeds best in thin soils. Fruit a waxen yellow.

Red June, An attractive, brilliant red apple. fruit very juicy and of good quality.

Fanny. A very good variety for the home orchard, fruit a bright red and of very good quality.

Duchess. Hardy and vigorous in growth, an abundant producer, fruit streaked and shaded red.

\section{AUTUMN VARIETIES}

Maiden Blush. An old and well known variety; pale yellow with a bright pink cheek.

Wealthy. Tree very hardy, fruit large, varying from a striped to a brilliant red; the best of its season. Being very hardy and a young bearer, it is especially valuable for cold climates.

Snow (Fameuse). Another well known and popular sort. Fruit of medium size, striped crimson.

IVolf River. One of the largest apples grown; tree very hardy; fruit greenish yellow shaded crimson.

\section{EARLY WINTEI: VARIETIES.}

Milwaukee. A seedling of the Duchess, fine for either cooking or table use, striped crimson.

MeIntosh Red. A seedling of the Snow, fruit medium to large, tree very vigorous.

Grimes Golden. Tree hardy and vigorous, fruit golden yellow and of the best quality.

\section{IVINTER VARIETIES.}

Talman Sweet. Tree long lived and very hardy; a reliable cropper, bearing t an early age. Fruit yellow tinged red.

Northwestern Greening. Tree exceedingly hardy, fruit large and a good keeper, greenish yellow.

Delicious. A comparitively new apple, brilliant red in color and of a very good quality. Tree thrifty and a good cropper.

Winter Banana. A good grower, bears young and annually, fruit pale yellow with bright pink cheek.

Jonathan. A bright red apple of medium size, very tender and juicy. It is probably the best known of the commercial varieties and is one of the best of our desert apples. At its best here in the middle west.

Yorki Imperial. A vigorous grower. and a good cropper. Fruit bright red. of good quality and a long keeper.

Bayard. An early cropper. Fruit large, of a rich, deep red.

Stayman's Winesap. A stronger grower than the Winesap and will thrive on thin soils. Fruit a dark red, indistinctly striped, quality very good.

Stark. A very good keeper, fruit large, yellow shaded red.

Salome. One of the best all purpose winter apples, whether planted for the commercial or the home orchard. Tree very hardy and a vigorous grower; fruit of good size and of excellent flavor, a good keeper.

Willow Twig. A well known sort, greenish yellow, keeps well into June.

Winesap. Tree hardy and a regular cropper, but does not thrive on thin soil. Fruit dark red, a good shipper. 


\section{CRAB APPLES}

50 cents each: $\$ 4.00$ per 10 .

Whitney. A small apple rather than a true crab. Tree very hardy. Fruit juicy, of a good flavor, yellow splashed crimson.

Florence. A young and prolific bearer; one of the best, unsurpassed for jellies.

Hyslop. A large deep crimson crab. Popular because of its size and beauty.

\section{STANDARD PEARS}

The Pear succeeds best on a heavy and well drained soil, but will do well on a rich loam or sand, with good bottom. The fruit will keep longer and its flavor will be greatly improved by picking before it is quite mature, and ripening in the house. Many of the choicer varieties of pears are self sterile and for this reason several varieties should be planted close together. Plant the trees twenty feet apart each way, keep them cultivated until August, and thin the fruit on the trees when it is about half grown. We list only those which do well in Illinois.

75 cents each; $\$ 7.00$ per $10 ; \$ 50.00$ per 100 .

\section{SUMMER. VARIETUES.}

Koonce. Tree very hardy. One of the largest and most prolific of the early pears.

Wilder. Tree a young bearer and a heavy cropper. Fruit of medium size and excellent quality.

Bartlett. A well known variety of fine flavor. Bears young and abundantly, but is quite susceptible to blight.

Vermont Beauty. A strong vigorous grower and good bearer. Fruit of medium size and excellent quality.

\section{AUTUMN VARIETIES.}

Lincoln. A strong, vigorous, healthy grower. Fruit averages larger than the Bartlett. One of the best of its season.

Flemish Beauty. Tree very hardy and vigorous. Fruit large and beautiful.

Seckel. Tree hardy; fruit small and yellowish brown, but of the highest flavor. A standard for quality among pears.

\section{WINTER VARIETIES.}

Garber. Tree hardy and healthy. A large, juicy pear of fair quality.

Kieffer. Tree a vigorous grower and early bearex. Fruit large and very juicy, but somewhat coarse. The best market variety and also the variety which does best in this part of the country.

\section{DWARF PEARS}

Pears are dwarfed by working them on Quince stocks. Care should be taken in planting to see that the union between the Pear and the Quince is buried from three to four inches. We list only those varieties which succeed best as dwarfs.

Strong trees, 3 to 4 feet, 50 cents each; $\$ 4.50$ per $10 ; \$ 40.00$ per 100 .

Duchess. Hardy and best as a dwarf. A most dependable cropper and an all around profitable pear.

Anjou. Succeeds everywhere and is one of the best. Fruit large, very juicy, and of excellent quality.

\section{PLUMS}

Tho it does fairly well in almost any soil not thoroughly wet, the Plum produces its finest fruits and surest crops on a heavy, clayey soil. They should be well cultivated to obtain the best results. All of those we offer are budded on hardy plum stock.

75 cents each; $\$ 7.00$ per $10 ; \$ 50.00$ per 100.

\section{JAPANESE VARIETIES.}

Abundance (Botan). One of the most popular of the Japanese sorts. Fruit large, bright red, firm and sweet.

Burbank. A good, dependable plum, one of the best for either garden or market planting. Large, clear red, very sweet.

Red June. A very early sort. Tree healthy and hardy and succeeds everywhere. A showy, attractive plum.

\section{EUROPEAN. VARIETIES.}

Bradshaw. A large, handsome, bluish purple plum; very productive and fine for marketing.

Damson. Bears enormous crops of small, deep purple plums, especially prized for preserving.

German Prune. A large, oval, dark blue variety.

Lombard. Medium size, of very good quality, color violet red.

\section{NATIVE VARIETIES,}

DeSoto.' Probably the most grown of any Plum of this type. Tree is of iron clad hardiness. Fruit of medium size, red; flesh yellow and firm, of very good quality.

Wyant. One of the best. Fruit purplish red and of good quality. 


\section{CHERRIES}

The Cherry is one on the finest and most delicate of our desert fruits. The trees thrive well in any soil which is sufficiently well drained, but will not succeed where the sub-soil is wet. We list only the sour varieties. The sweet sorts are of very little value in this section of the country, as they but seldom fruit.

75 cents each; $\$ 6.00$ per $10 ; \$ 50.00$ 1) 100.

Dyehouse. One of the best of its season for market or home use. It is larger, finer and of better quality than the Early Richmond, and ripens a full week earlier.

Farly Richmond. Medium size, clear bright red, quite acid. A good market sort. Tree a free grower and productive.

Iarge Montmorency. The best of all of the sour cherries. It forms the most perfect tree, is less subject to disease, is less affected by wet weather, is the heaviest betarer, and bears the best fruit of all of the sour cherries. The fruit is very large, of a fine flavor, a clear bright red, and ripens a week later than the Richmond.

Late Duke. The best of the Dukes. A large, heart-shaped Cherry, very lark red, almost black. Ripens the last of July.

Fnglish Morello. Tree small and of spreading habit. Fruit dark red or nearly black and very acid.

Wragg. Of the Morello type but larger. Bears young and is an abundant and regular bearer.

\section{PEACHES}

Peaches require a well drained moderately rich soil, a warm sandy loam probably being the best. No fruit responds more quickly to intelligent cultivation, or more rapidly deteriorates with ship-shod handling, than does the Peach. In order to preserve the continued healthy growth of the trees and the fine quality of the fruit, the trees should have careful and severe pruning at least every two years, so as to preserve, a round vigorous head with plenty of new wood.

50 cents each; $\$ 4.00$ per $10 ; \$ 25.00$ per 100.

Mayflower. The earliest Peach; perfectly hardy and a good cropper. Fruit red, of medium size. The best early Peach. Semi-cling.

Carman. Hardy, a regular bearer, fruit large, yellowish white splashed with red; a fine sort. Free-stone.
Alton. Very hardy in tree and bud; a large white peach with a handsome red cheek; quality of the best. Freestone.

Lindsey. Originated in Davenport, Iowa. Exceptionally hardy, with large glossy foliage; a good grower and a heavy cropper; fruit large; yellow with a red cheek; one of the best. Freestone.

Banner. One of the later sorts. Fruit vellow with a deep crimson blush; of excellent quality.

Waddell. Creamy white with a bright blush, of very good quality. Free-stone.

Hiley. A large white peach, a fine shipper. Very hardy in both wood and bud. Free-stone.

Fitzgerald. A large, bright yellow, mid-season Peach. Tree hardy and an early bearer. Free-stone.

Champion. A large creamy white Peach with a light blush. Extremely hardy and of splendid quality. Mid-season free-stone.

Stump. A large white Peach with a bright red cheek, ripening quite late. Free-stone.

Hills Chili. A medium large, dull yellow free-stone. Very hardy and productive.

Wonderful. A large yellow freestone, ripening quite late. A very desirable market variety.

Early Crawford. A large yellow freestone of good quality; a good commercial variety. Tree hardy and a vigorous grower.

Elberta. A large yellow free-stone, ripening in mid-season. The most widely planted commercial variety, productive, dependable, a good shipper, and of fair quality.

Tate Crawford. An extra large yellow free-stone of high quality, one of the best of the late peaches. A good shipper and a profitable commercial variety when planted on fertile soil.

Crosby. The best and hardiest late yellow peach for planting in the north. A high quality free-stone, especially good for canning.

Heath Cling. The latest peach of all. Fruit large and white, of good quality, highly prized for preserving and pickles.

\section{QUINCES}

The Quince requires but little space, is quite productive, and does well in almost any good garden soil. We list the most desirable sorts in extra good stock, grown in tree form, 3 to 4 feet high.

50 cents each; $\$ 4.50$ per 10 .

Champion Orange Bourgeat




\section{GRAPES}

Grapes require a mellow, well drained soil and a ivarm, sunny exposure. They require but little space, are easily grown, and give large returns for the care given them. We list the varieties which we believe to be the best for general planting.

rhe prices of grapes for strong 2 year plants are, except where otherwise noted, 25 cellts each; $\$ 2.00$ per $10 ; \$ 10.00$ per 100 .

Brigliton. Vine thrifty and a strong grower. A large, delicious, sweet, red grape.

Canpbell's Early. A strong, vigorous grower of the Concord type, but much earlier and of a better quality. Fruit large and black.

35 cents each; $\$ 3.00$ per $10 ; \$ 15.00$ per 100 .

Concord. An old stand-by, the best market sort. Vines remarkably hardy, rigorous, and productive. Fruit large and purplish black.

Each Per 10 Per 100 Strong 2 year vines $\ldots \$ .20 \quad \$ 2.00 \quad \$ 8.00$ Strong 1 year vines .. $.15 \quad 1.00 \quad 6.00$

Delaware. Fruit small, exceedingly sweet, light red. Bunches small and compact.

Niagara. A large white grape, bunches large and handsome. Succeeds almost anywhere.

Moore's Farly. Ripens very early, one of the most valuable of the black sorts.

Moore's Diamond. The best white grape for this section; hardy, vigorous, and productive, the most satisfactory of its color and season.

Woodrufi. A very handsome red grape, large in both bunch and berry.

Worden. A valuable and dependable black grape, a little earlier than the Concord.

\section{CURRANTS}

To do well, Currants require a rich, fertile soil and thorough cultivation. The bushes should be pruned each year to keep the old wood out and the bushes open.

Fxcept where otherwise noted, the prices of Currants are 20 cents each; $\$ 1.50$ per $10 ; \$ 2.50$ per $25 ; \$ 8.00$ per 100.

Black Champion. Very productive, large bunch and berry.

Fay's Plolific. Very productive, berries red, exceedingly large.
Perfection. Berries very large and a beautiful bright red. A heavy cropper and superior to any other large sort.

25 cents each; $\$ 2.00$ per $10 ; \$ 4.00$ per $25 ; \$ 15.00$ per 100 .

White Grape. Berries very large and yellowish white, of excellent quality.

White Imperial. The sweetest and richest white currant extant. Hardy and productive. The best of all for a desert fruit.

25 cents each; $\$ 2.00$ per $10 ; \$ 4.00$ per $25 ; \$ 15.00$ per 100 .

Wilder. One of the strongest and most productive of the red currants, berries very large.

\section{GOOSEBERRIES}

Plant in good rich soil and give a liberal dressing of manure each season. Regular pruning each year is essential for the production of fine fruit.

15 cents each: $\$ 1.50$ per $10 ; \$ 12.00$ for 100 .

Downing. Large, pale green, and of splendid quality. A vigorous grower.

Houghton. Small, dark red, thin skinned, a heavy cropper.

Josselyn (Red Jacket). Probably the best of the large fruited American sorts. Hardy and of the best quality.

Pearl. A little larger and more prolific than Downing.

\section{BLACKBBERRIES}

Blackberries should receive much the same general treatment as Raspberries. The pruning should be governed by the growth and should be severe. Pinch back the shoots when they have reached a height of three or four feet.

Except where otherwise noted, the prices on Blackberries are 50 cents per dlozen; $\$ 3.00$ per $100 ; \$ 15.00$ per 1000 .

Ancient Britton. One of the best hardy varieties, vigorous and healthy.

Fldorado. A strong hardy grower and a good shipper. Jet black when ripe.

Erie. Hardy and free from rust. Berries large and of an excellent quality.

Suyder. Very hardy and exceedingly productive. Fruit medium size, sweet and juicy.

Joy. An extremely hardy and very productive new Blackberry ripening in mid-season. The berries are very large and very black and of a wonderfully sood quality.

10 cents each; $\$ 2.00$ per $25 ; \$ 5.00$ per 100 . 


\section{RASPBERRIES}

Raspberries will do well on any soil that will produce a good corn crop. The land should be thoroughly prepared and well enriched before planting; ground bone is one of the best fertilizers. Keep well cultivated and free from weeds and suckers. As soon as they are through bearing, cut out the old canes to give more vigor to the young ones. Plant in rows seven feet apart, three feet apart in the rows.

\section{SPECIAL SORTS.}

10 cents each: $\$ 2.00$ per $^{*} \mathbf{2 5} ; \$ 5.00$ per 100

Perfection. A new red variety, a very strong grower. The berries are bright crimson, mammoth, and very uniform in size. It is one of the earliest to ripen and continues in fruit through a very long season. It is by far the most productive red Raspberry that we know.

St. Regis. This variety has been aptly termed "the early till late" Raspberry for it is the first red sort to ripen fruit and it continues to produce berries without intermission until October. It is of iron clad hardiness and wonderfully prolific. The berries are bright crimson, of large size and fine quality. It succeeds in all soils and should be more generally planted.

Scarff. A new and very attractive black-cap, with large, firm fruit of uniform size. It is a late berry, commencing to ripen only a few days before Gregg, and remaining in fruit through a long period. It is more productive than the average black-cap and a very good market variety.

\section{THE BEST OF THE OLDER SOR'TS}

$\$ 1.00$ рен $10 ; \$ 1.50$ per 25; \$3.00 per 100.

Cumberland. A healthy and vigorous grower, producing very large crops. Fruit a good black, very large and firm. A profitable market sort.

Cuthbert. The best of the older sorts of red Raspberries. Fruit very large and firm.

Columbian. A large fruited purple Raspberry very good for canning.

Kansas. A strong vigorous grower, ripens early and is considered one of the best of the older black sorts.

King. The best early red Raspberry. A strong grower, hardy and productive.

Gregg. The most productive late black variety, berries very large and firm.

Plum Farmer. The best early black variety, berries thick meated, large, and firm.

\section{STRAWBERRIES}

Strawberries will succeed in any good rich soil that is well drained and cultivated. After the ground is slightly frozen in the winter cover them with a little straw or leaves. Do not cover them so deeply as to smother them and remove the litter before growth begins in the spring.

Good varieties must be planted if good crops are wanted. We test all of the new varieties and offer here only those that are of good value.

Strawberry plants should always be shipped by themselves, by express or mail, and packed separately from other goods. Good thrifty plants will be furnished and our responsibility ceases on delivery. We do not replace Strawberry plants and prices are made with this understanding.

Except where otherwise noted, the prices on Strawberries are: $\$ 1.00$ for 25: $\$ 1.50$ per $100 ; \$ 8.00$ per 1000 .

Dr. Bumill. A new variety, just introduced; a vigorous grower and a heavy cropper. The berries are dark red throughout and very juicy; splendid keepers and good shippers. Of it the introducer says

"Almost everyone who has grown Strawberries has grown Senator Dunlap and knows that it is an unusually heavy fruiter; also that it produces high quality berries. Last season we had Dr. Burrill and Senator Dunlap fruiting side by side, and while there is a great resemblance both in the fruit and the plant of these two varieties, there is a vast difference in the quality and quantity of berries produced by each, and this difference is in favor of Dr. Burrill. The Burrill plants were simply red with berries of large size and most delicious flavor."

$\$ 1.00$ for $25 ; \$ 3.00$ per $100 ; \$ 20.00$ per 1000 .

Bubach. This variety was originated here at Princeton and is an old favorite of thirty years standing. The berry is thick, broad, and irregular; of a bright scarlet red color and of very good quality. It is famous for its productiveness and the size of its berries. One of its most unusual qualities is its adaptibility to any kind of soil.

Dunlap. The standard for excellence in Strawberries. The plant is one of the most vigorous and hardy grown; a heavy cropper, a good shipper, and of fine quality. The fruit is large and conical in form and a deep rich red in color. Begins to ripen just after the earliest sorts and continues in fruit over a long season. 
Strawberries-Continued.

Gibson. An excellent all-around Strawberry; a very heavy cropper and a good shipper. It commences to ripen with Dunlap and continues through a long season, making a very heavy yield of fruit. The berry is large, globular, and deep red; it keeps its size until the end of the season. A better cropper and of somerhat better quality than the Dunlap.

In addition to the varieties named above the best of the older sorts, listed in the order of their ripening, are:

\section{Bederwood Haverland Marshall}

lovett clyde Aroma.

Warfield crescent Gandy

\section{Glen Mary}

FML BEARING VARIEIIES.

Fall Bearing Strawberries are something comparitively new, but each succeeding season proves still more what a valuable addition they are to our list of garden fruits. They have been thoroughly tested and have proven to be all that has been claimed for them. They fruit in the spring as heavily as any other variety and again come into bearing after the fall rains begin, continuing to bear large berries of excellent quality until heavy frosts. All blossoms should be removed from newly set plants until about the middle of August in order that the plants may have a chance to make up.

$\$ 1.00$ per dozen: $\$ 2.00$ per 25: $\$ 3.00$ per $50 ; \$ 5.00$ per 100.

Americus. Plant of medium size, with a good heavy root system; a fairly good plant maker. The fruit is light red, heart shaped, of fine texture and good quality. Fruit stems stout, holding the fruit well up off of the ground. With us this is the heaviest cropper of all of the fall bearing sorts.

Progressive. We have found this to be the best fall bearing variety. A vigorous thrifty grower and the best plant maker of the lot. In color of the foliage, size and shape of the berry, and manner and habit of growth it much resembles the Dunlap. Fruit medium to large in size, of a beautiful glossy red color; flesh firm and of good quality.

Superb. This variety bears extremely large and firm berries of excellent quality, but is not as good a cropper as either of the other two varities listed. A vigorous, thrifty plant; bearing fruit of a beautiful bright crimson. which run remárkably even in size and shape.

\section{GARDEN ROOTS}

RIIUB.IIB. Make the bed very rich and deep; top dress annually with manure and fork under in the spring. Set the roots so that the.crowns are about an inch below the surface and plant in rows four feet apart.

Early Scarlet. Mratt's Limnacus, Victoria, 20 cents each; $\$ 1.00$ per 10 .

ISPIRIGCS. Requires a deep rich soil. Top dress annually with stable manure and fork under in the spring. We sell Asparagus roots only in mul- tiples of 25 . All plants furnished are strong 2 year roots.

Palmetto and Mammoth Per 100 Per 1000
White ...........\$1.50 $\$ 10.00$ Giant and Conover's

Colossal ........... $1.00 \quad 6.00$

HORSE MADISH. We offer strong plants of a Russian variety recently introduced by the Bureau of Plant Industry. This Horse Radish is famous for its fine qualities and in especial demand in Russia during the winter holidays.

25 . cents each; $\$ 2.00$ per 10 . 


\section{Ornamental Department}

\section{DECIDUOUS TREES}

In planting deciduous trees we cannot too strongly emphasize the importance of the proper preparation of the ground. The hole should be dug at least two feet wider in diameter than the roots require and deep enough to allow them to spread out in their natural order. Where the soil is poor, good soil should be brought in and thoroughly packed around the roots. Until they are well established tall trees should be staked.

We include in this list only such upright and weeping trees as our experience has shown are best suited to this climate and locality.

\section{ACER. Maples.}

A. dasycarpum (Soft or Silver Maple). A native species of rapid growth, large size, and irregular rounded form; foliage light green above, silvery beneath.

Each Per 10 5 to 6 . ft. $\ldots \ldots \ldots \ldots \ldots . .50 \$ 3.50$ 6 to $8 \mathrm{ft} \ldots \ldots \ldots \ldots \ldots \ldots . . . \ldots \ldots$ 8 to $10 \mathrm{ft} \ldots \ldots \ldots \ldots \ldots \ldots . \ldots 1.00 \quad 7: 00$ 10 to $12 \mathrm{ft} \ldots \ldots \ldots \ldots \ldots 1.50 \quad 10.00$

A. dasycarpum Wierii (Wier's Cutleaved Silver Maple). A form of the Silver Maple with slender drooping branches and very finely cut leaves. It is one of the largest and most desirable of the weeping trees.

8 to $10 \mathrm{ft} \ldots \ldots \ldots \ldots$ Each

10 to $12 \mathrm{ft} \ldots \ldots \ldots \ldots \ldots \ldots \ldots+\ldots \ldots \ldots \ldots \ldots$

2 in. through ........... 2.50

A. platanoides (Norway Maple). 60 feet. A large, handsome tree of spreading, rounded form, with a broad deep green shining foliage. Its compact habit and symmetrical growth make it especially desirable for street planting.

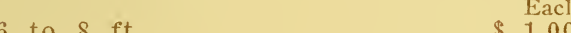

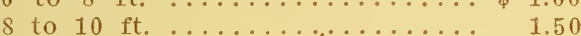

A. platanoides Schwedlerii (Schwedler's Norway Maple). 40 feet. The young leaves and shoots are purplish, changing to a deep green as they mature.

Each

5 to $6 \mathrm{ft} . \ldots \ldots \ldots \ldots \ldots \ldots \ldots \ldots \$ \ldots \ldots \ldots \ldots$

6 to $\&$ feet ................ 2.50

A. saccharinum (Sugar or Rock Maple). 80 feet. A stately native tree of dense upright growth, forming a large, well rounded head.

5 to $6 \mathrm{ft} . \ldots \ldots \ldots \ldots \ldots \ldots \ldots \$ \ldots \ldots$

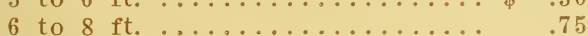

$s$ to $10 \mathrm{ft} . \ldots \ldots \ldots \ldots \ldots \ldots . \ldots . \ldots 1.00$
A. tataricum ginnala (Siberian Maple). 10 feet. A shrub or small tree with handsome foliage turning dark red in the autumn.

2 to 3 ft. $\ldots \ldots \ldots \ldots \ldots \ldots \ldots \ldots \begin{gathered}\text { Each } \\ .50\end{gathered}$

3 to $4 \mathrm{ft}, \ldots \ldots \ldots \ldots \ldots \ldots \ldots . .75$

AESCULUS. Hor'se Chestunt.

IE. hippocastenum (European Horse Chestnut). 50 feet. A compact tree with large compound leaves and showy spikes of white flowers in the spring.

6 to $8 \mathrm{ft} \ldots \ldots \ldots \ldots \ldots \ldots \ldots$

8 to 10 ft. ............. 2.00

MITANTHUS.

1. glandulosus (Tree of Heaven). 40 feet. A very rapid growing tree with large compound feathery leaves sometimes 6 feet long. It will grow in the poorest of soils and will stand very hard treatment. It is the best shade tree in crowded city sections where there is but little. light and planting space.

6 to 8 ft. ............. $\$ 1.00$

8 to $10 \mathrm{ft} . \ldots \ldots \ldots \ldots \ldots \ldots . \ldots \ldots$

10 to $12 \mathrm{ft} . \ldots \ldots \ldots \ldots \ldots \ldots \ldots .2 .00$

\section{BETCLA. Birch.}

B. alba (European White Birch). 50 feet. A rapid growing tree with silvery white bark and spray-like branches. Each 5 to $6 \mathrm{ft} . \ldots \ldots \ldots \ldots \ldots \ldots \ldots \$ 1.00$

B. alba pendula laciniata (Cut-leaved Weeping Birch). 50 feet. The most popular of all weeping trees. Tall and slender with graceful, drooping branches Very hard to transplant after they become large. 


\section{C.ISTANEA. Chestnut.}

C. americana (American Chestnut). 50 feet. A well known native nut-bearing tree of spreading growth.

3 to $4 \mathrm{ft} . \ldots \ldots \ldots \ldots \ldots \quad \begin{array}{r}\text { Each } \\ .75\end{array} \quad \begin{aligned} & \text { Per } 10 \\ & 6.00\end{aligned}$

4 to 5 ft. .......... $1.00 \quad 7.50$

\section{C.ITALPA.}

C. Bungei. A very dwarf Chinese species grafted on stems about six feet high. The foliage is large, glossy, and heart-shaped; and forms a very symmetrical globular head.

Each

1 year heads; $6 \mathrm{ft}$. stems ..... \$ 1.25

2 year heads; $6 \mathrm{ft}$. stems ...... 1.50

C. speciosa (Hädy or Western Catalpa). 60 feet. An open, spreading tree of irregular growth with very large. leaves, bearing in July terminal spikes of large, showy, fragrant flowers.

$\&$ to $10 \mathrm{ft} \ldots \ldots \ldots \ldots \ldots \$ \$ 1.00 \$ 7.50$ 10 to $12 \mathrm{ft} . \ldots \ldots \ldots \ldots \ldots . \ldots 1.25 \quad 10.00$ 2 in. through ........ $1.50 \quad 12.50$

FR.IXINUS. Ish.

F. americana (American Ash). 60 feet. A native tree of very rapid growth.

5 to $6 \mathrm{ft} . \ldots \ldots \ldots \ldots \ldots \ldots \ldots \ldots \$ \ldots \ldots$

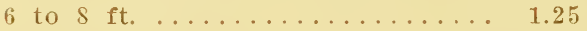

\section{GINTigo.}

G. bilobat (Salisburia or Maidenhair Tree). 50 feet. A slender, pyramidal tree with very unusual fan-shaped leaves.

Each

\section{GLEDITSCHIA. Locust.}

G. Iriacanthos (Honey Locust). 40 feet. A rapid growing native tree with delicate foliage and large thorns. Bears in May long racemes of pea-shaped flowers.

5 to $6 \mathrm{ft} . \ldots \ldots \ldots \ldots \ldots \ldots \ldots \ldots \ldots \ldots$

6 to 8 ft. $\ldots \ldots \ldots \ldots \ldots \ldots \ldots . . .75$

\section{GYMNOCLADUS.}

G. canadensis (Kentucky Coffee Tree). A graceful tree of open growth with odd, tropical looking foliage.

Each

$s$ to $10 \mathrm{ft} . \ldots \ldots \ldots \ldots \ldots \ldots \ldots \$ 1.00$

\section{JUGLANS. Walnut.}

J. nigra (Black Walnut). 80 feet. A majestic native tree with a symmetrical round-topped crown.
J. Sieboldiana (Japanese Walnut). A medium-sized round-headed tree native of Japan. The nuts, which resemble the butternut in shape, are borne in hanging clusters.

Each

\section{TIRIODENDIRON.}

L. tulipifera (Tulip Tree). 80 feet A rapid growing tree with dark green foliage which bears a large number of fragrant tulip-shaped flowers.

Each

5 to $6 \mathrm{ft} . \ldots \ldots \ldots \ldots \ldots \ldots \ldots 1.00$

6 to 8 ft. $\ldots \ldots \ldots \ldots \ldots \ldots \ldots \ldots, 1.50$

\section{MAGNOLIA.}

There is probably no place in the Middle West where there are more Magnolias growing and thriving at the present time than in our little city of Princeton. Some of the trees are between fifty and sixty years old, others have been out only a few years. Arthur Bryant. Senior, some sixty years ago started to propagate and sell them and many of the trees he planted are still vigorous, healthy specimens. Each season before the leaves appear their gorgeous masses of colored bloom are at their best, and their fragrance is as delicious as their color is pleasing.

The trees offered will all have bloom buds and will be balled and burlaped. which will insure their transplanting safely.

Ir. accuminata (Cucumber Tree). 60 feet. A symmetrical conical tree with large ornamental leaves, often eight inches long. Flowers creamy white in May. Fruits in the shape of a cucumber, scarlet.

Each 5 to $6 \mathrm{ft} . \ldots \ldots \ldots \ldots \ldots \ldots \ldots 1.50$

M. conspicua (Yulan.) A low branched tree of meáium height; covered before the leaves appear with large, white bellshaped flowers which are sweet scented and almost six inches across. 3 to $4 \mathrm{ft} \ldots \ldots \ldots \ldots \ldots \ldots \ldots \ldots 3.0 \ldots$

M. glanca (Sweet Bay). 30 feet. A very handsome small tree with long glossy leaves, evergreen in the south. The flowers are white, fragrant, cupshaped, and very abundant.

2 to 3 ft. ............. \$ 2.50

M. stellata (Hall's Magnolia). $\&$ feet. A very beautiful dwarf tree with large, star-shaped, fragrant white flowers, the first of the Magnolias to bloom in the spring. Very hardy. 
M. Soulangeana hybrids (Hybrid Chinese Magnolias). These are large shrubs or small trees with dark green ovate leaves expanding after the flowers have fallen. The flowers are large, cupshaped, and fragrant, and at blooming time cover the tree. Very hardy.

Soulangeana-white to rosy violet

Each, $\$ 2.00$

Sonlangeana nigra - dark rose

Each $\$ 3.00$

Soulangeana Lennei-deep crimson. later than the others. Each $\$ 3.00$

\section{MORUS. Mulberry.}

M. alba tatarica (Russian Mulberry). A low growing tree with a much branched crown and edible fruit.

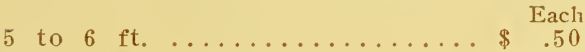

6 to $8 \mathrm{ft.} \ldots \ldots \ldots \ldots \ldots \ldots . .75$

M. alba tatarica pendula (Tea's Weeping Mulberry). A small tree with long slender branches drooping to the ground. one of the best of the weeping trees.

$1 \mathrm{yr}$. heads ...........\$ $\$$ Each 1.75

2 yr. heads ............. 2.50

\section{platinus.}

P. occidentalis (Buttonwood, Sycamore, or American Plane). A large lofty tree with wide spreading branches, probably the tallest of all of the native deciduous trees of North America. The bark is a picturesque gray-green.

Each

5 to $6 \mathrm{ft} \ldots \ldots \ldots \ldots \ldots \ldots \ldots \ldots \ldots \ldots \ldots$

6 to 8 ft. ............... 1.00

8 to $10 \mathrm{ft} . \ldots \ldots \ldots \ldots \ldots \ldots . \ldots \ldots$

P. orientalis (Oriental Plane). Forms a broad round head on a comparitively short trunk. Leaves larger than those of the American Plane. Often used for street planting.

Each

6 to $8 \mathrm{ft} . \cdots \cdots \cdots \cdots \cdots \cdots \cdots \cdots \cdots \cdots \cdots$

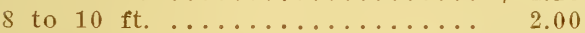

POPtuUs. Poplar.

P. deltoides carolinensis (Carolina Poplar). A symmetrical and very rapid growing tree, making an upright or pyramidal head. The most popular and most widely planted of all of the poplars.

\begin{tabular}{|c|c|c|}
\hline & Each & Per 10 \\
\hline 6 to $8 \mathrm{ft} . \ldots$ & $.35 \$$ & 2.50 \\
\hline 8 to $10 \mathrm{ft} . \ldots$ & .50 & 3.50 \\
\hline 10 to $12 \mathrm{ft} . \ldots$ & .75 & 5.00 \\
\hline 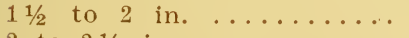 & 1.00 & 7.50 \\
\hline to $2 \frac{1 / 2}{2}$ in. $\ldots \ldots \ldots \ldots \ldots$ & 2.00 & \\
\hline
\end{tabular}

P. deltoides carolinensis rar. (Norway Poplar. A form of the Carolina Poplar of even more rapid growth. Prices the same as for the Carolina Poplar.

P. nigra italica (Lombardy Poplar). 50 feet. A tall columnar form in contrast to the other round-headed poplars. They branch from the ground and make a very effective screen planting.

Each Per 10

5 to $6 \mathrm{ft} . \ldots \ldots \ldots \ldots \ldots \ldots \$ .50 \$ 4.00$

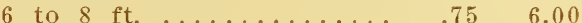

8 to $10 \mathrm{ft} . \ldots \ldots \ldots \ldots \ldots \ldots \ldots \ldots$

10 to 12 ft. .......... $1.50 \quad 10.00$

\section{PRUNUS. Plum.}

P. Pissardi (Purple-leaved Plum). 10 feet. A small tree with a wide, open growth and rich purple leaves which retain their color through the summer.

3 to 4 ft. ............ $\$ \ldots .75$

4 to $6 \mathrm{ft} . \ldots \ldots \ldots \ldots \ldots \ldots \ldots \ldots, 1.00$

PYRUS. Crabs.

P. coronaria (Wild Crab-apple). 20 feet, pink, May. A small spreading tree producing an abundance of showy and fragrant flowers followed by a large yellow fruit.

3 to $4 \mathrm{ft.} \ldots \ldots \ldots$

4 to $6 \mathrm{ft} . \ldots \ldots \ldots \ldots \ldots \ldots \ldots$

P. floribunda Parkmani (Parkman's Double-flowering Crab). A dwarf compact grower with dark green leaves that hang late on the tree. Flowers dark rose and very double.

t to 5 ft. . . Each

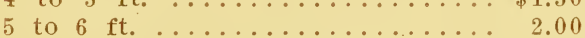

P. ioensis Bechtelii (Bechtel's Double-flowering Crab). Tree of medium size, covered in the spring with large, double, fragrant flowers of a delicate pink color. One of the best of the Flowering Crabs.

3 to 4 ft $\ldots \ldots \ldots \ldots$

4 to 5 ft. $\ldots \ldots \ldots \ldots \ldots \ldots \ldots \ldots \ldots \ldots$

\section{QUERCUS. Oaks.}

Q. alba (American White Oak). 80 feet. One of the finest of the American trees forming a broad, open, symmetrical head with spreading branches.

5 to $6 \mathrm{ft}$. ........... $\begin{array}{r}\text { Each } \\ 1.50\end{array}$

Q. macrocarpa (Burr or Mossy-cup Oak). A large tree with massive spreading branches forming a broad head. The acorn is deeply enclosed in a mossy cup.

5 to 
Q. palustris (Pin Oak). A most attractive species, forming a symmetrical pyramidal head. The leaves are very deeply cut.

6 to $8 \mathrm{ft} . \ldots \ldots \ldots \ldots \ldots \ldots \ldots \ldots \$ \ldots$

Q. rubra (Red Oak). A native tree with spreading branches forming a broad head. The most rapid grower of the caks.

Each $\$ 1.50$

sOrBUs. Mt. Ash.

S. aucuparia (European Mit. Ash). A small round-headed tree of fairly upright growth with large clusters of scarlet fruit in the fall.

5 Each

6 to $8 \mathrm{ft} . \ldots \ldots \ldots \ldots \ldots \ldots \ldots, 1.50$

S. ancuparia pendula (Weeping Mt Ash). Branches slender and pendulous, reaching to the ground. Fruit clusters very showy.

ds ............. \$1.50

2 yr. heads ............... 2.00

\section{TAXODIUM.}

T. disticm (Deciduous or Bald Cypress). 40 feet. A tall narrow conical tree with foliage resembling that of the Larch.

5 to $6 \mathrm{ft}, \ldots \ldots \ldots \ldots \ldots \ldots \ldots 1.00$

\section{TrufA. Linden.}

'T. americana (American Linden). 60 feet. A rapid-growing native tree which developes a large, broad, open head.

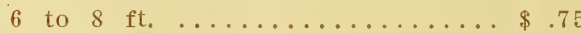

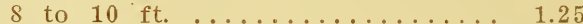

10 to 12 ft. ............... 2.00

2 in. through ............... 2.50

3 in. through $\ldots \ldots \ldots \ldots \ldots \ldots \ldots 5.00$

\section{ULMUS. FIm.}

U. americana (American White Elm). 80 to 100 feet. The most desirable tree for either lawn or street planting. A tall, graceful, wide-spreading tree with outward curving and pendulous bianches. We carry a large stock of sturdy, well trained trees grown from the seed of trees selected for their spreading vase-like shape.

Each Per 10 8 to $10 \mathrm{ft} . \ldots \ldots \ldots \ldots \ldots \$ .75 \$ 5.00$ 10 to $12 \mathrm{ft} . \ldots \ldots \ldots \ldots \ldots, 1.00 \quad 7.50$ $1 \frac{1 / 4}{4}$ to $1 \frac{1 / 2}{2}$ in. ......... $1.25 \quad 10.00$

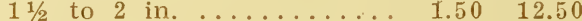
2 to $2 \frac{1}{2}$ in. .......... 2.00

U. scabra pendula (Camperdown or Weeping Elm). A form of the Scotch Elm with long pendulous branches reaching to the ground, the limbs spreading horizontally.

1 yr. heads ............ $\$ 250$ 


\section{EVERGREENS}

We do not include many Evergreens in this Catalog. having cut down our lists to the few varieties that we know will thrive in Illinois.

Evergreens should be moved in the spring just before they begin their growth, or during August and early September. if favorable weather prevails at that time. In transplanting, extreme care must be taken to see that the roots are never allowed to diy out, as that is almost surely fatal. Evergreens can be most successfully moved when each plant is lifted with a ball of earth and these prices include digging in this manner and securing the ball with burlap.

The weather conditions immediately following the moving of Evergreens, the care which the plants receive during and after planting, and other conditions over which we have no control, make the work so uncertain that, at the prices listed, we cannot guarantee them.

\section{ABIES. Fir.}

A. balsamea (Balsam Fir). 60 feet. Branches horizontal forming a broad regular pyramidal tree. Foliage dark green.

Each

18 to 24 in. ............. \$1.00

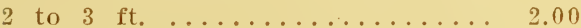

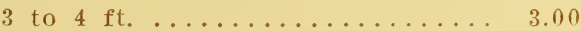

A. Fraseri (Fraser's Balsam Fir), 50 feet. A broad regular pyramidal tree. foliage dark green above, silvery bcneath.

Each

18 to $24 \mathrm{in} . \ldots \ldots \ldots \ldots$

2 to 3 ft. ................ 2.00

3 to 4 ft. ............... 3.00

JCNIPERUS. Juniper.

J. communis (Common Juniper). 4 feet. A native plant with spreading, sometimes prostrate, branches.

2 to 3 ft. ............. \$1.50

J. communis Hibernica (Irish Juniper) 10 feet. A small tree, stiff, nalrow and columnar in growth.

Each

2 to $3 \mathrm{ft} . \ldots \ldots \ldots \ldots \ldots \ldots \ldots \$ 1.50$

J. sabina (Savin's Juniper) 4 feet. A very attractive low evergreen with spreading or procumbent branches; foliage dark green.

$2 \mathrm{ft}$.

Each

J. virginiana (Red Cedar). 30 feet. A beautiful native evergreen, generally conical in growth, with upright branches and dark green foliage.

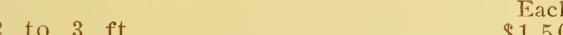

$\ldots \ldots \$ 1.50$

3 to $4 \mathrm{ft} . \ldots \ldots \ldots \ldots \ldots \ldots . \ldots \ldots$

PICFA. Spruce.

P. alba (White Spruce). 75 feet. Pyramidal and dense in growth, foliage silvery green.

- 2 to $3 \mathrm{ft}$
P. excelsa (Norway Spruce). 75 feet. Symmetrical in growth, with spreading. somewhat pendulous branches. A most useful tree for screens and wind-breaks. the most commonly planted of all of the Spruces.

18 to 24 in. ........... $\$ 1.00$

2 to 3 ft. ............. 1.50

3 to $4 \mathrm{ft} . \ldots \ldots \ldots \ldots \ldots \ldots \ldots 2.0 \ldots \ldots$

P. orientalis (Oriental Spruce). 30 feet. The most graceful and handsome of all of the spruces. The foliage is small and a deep lustrous green.

2 to 3 ft. ... Each

P. pungens slauca (Colorado Blue Spruce). 60 feet. Branches horizontal, stout, and in remote whorles, forming a broad symmetrical tree. Foliage rigid and a rich blue-green.

Each

$\$ 2.00$

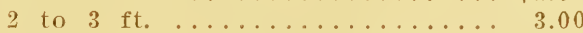

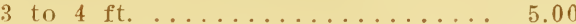

P. pungens Kosteriana (Koster's Blue Spruce). An especially blue type of the Colorado Blue Spruce. Sizes and prices the same as for the Colorado Blue spruce.

\section{PINUS. Pine.}

P. austriaca (Austrian Pine). 50 feet. A robust stately tree with a very broad head.

2 to 3 ft. ............ $\$ 1.00$

P. montana Mughus (Dwarf Mountain Pine). 8 feet. A low, handsome, compact evergreen with numerous ascending branches.

Each

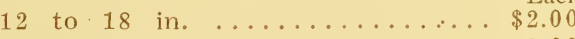

18 to 24 in. .............. 3.00

P. ponderosa (Bull Pine). 50 feet. Open spreading branches which are sometimes pendulous; needles very long. This Pine withstands better than any other Evergreen the hot dry summer's of the Middle West.

2 to $3 \mathrm{ft} \ldots \ldots \ldots+\ldots \ldots$ 
P. strobus (White Pine). 75 feet. The best known of the Pines. The branches are horizontal and leave the trunk in regular whorles. Very picturesque when old.

18 to 24 in. ............. $\$$ Each

2 to 3 ft. .............. 1.00

3 to 4 ft. ............. 2.50

THUYA. Arborvitae.

T. occidentalis (American Arborvitae). A small tree of variable height and pyramidal outline. On account of its dense growth it is used extensively for planting screens and hedges.

18 to 24 in Each

18 to 24 in. ............. \$1.00

2 to 3 ft. ................ 1.50

3 feet $\ldots \ldots \ldots \ldots \ldots \ldots \ldots \ldots 2.00$

T. occidentalis globosa (Globe Arborvitae). A pretty dwarf tree of a compact globose shape; very dense.

18 to 24 in Each

2 to 3 ft. .............. 5.00

T. occidentalis pyramidalis (Pyramidal Arborvitae). 10 feet. Narrow and columnar in growth. Each

2 to 3 ft. ............. $\$ 3.00$

3 to 4 ft. ............. 4.00
'T. occidentalis siberica (Siberian Arborvitae). A more compact grower than the type, forming a much broader head.

18 to 24 in. ................. 18 to 24 in. ............ $\$ 2.50$

\section{RHODODENDRONS and AZALEAS.}

Like practically all of the broad-leaved Evergreens, the Rhododendron is not adapted to the climate and soil conditions of the Middle West. It should be planted on a north slope, in a cool moist soil absolutely free fr»m lime and yet rich in vegetable humus, always protected from the direct rays of the sun. On account of our limestone soils, our extremely hot dry summers, and our variable winters, the Rhododendron does not thrive in this section of the country.

The Azalea, which is in reality a deciduous Rhododendron, does little better in the Middle West than does its evergreen relative.

We can offer Rhododendron catawbiense to color in white, rose, and lavendar at $\$ 3.00$ each, $\$ 5.00$ per pair. Azalea mollis at $\$ 1.00$ each. 


\section{DECIDUOUS SHRUBS}

Nothing will more enhance the appearance and value of a property than the planting of a few well selected shrubs. There are a few hard and fast principles, yet simple ones, governing the artistic arrangement of shrubs which should be more strictly observed. Generally speaking, individual specimens should but very rarely be separated from the body of the design. Irregular groups or masses arranged against buildings, fences or property lines, or as border plantations along walks and drives, are much more effective. A good arrangement invariably provides wide, open stretches of lawn.

Our collection of shrubs is extensive, but extremely practical. We have eliminated from this list all of those which for any reason do not do well in the climate and under the conditions prevalent in this section. of the country. We list the approximate height which the plant may be expected to attain, the color and the time of the bloom. Where no mention of the bloom is made, it is comparitively inconspicuous.

\section{AMORPHA.}

A. fruticosa (False Indigo). 10 feet, violet-purple, June. A strong growing shrub with long, loose-hanging clusters of pea-shaped flowers.

Each

2 to $3 \mathrm{ft} . \ldots \ldots \ldots \ldots \ldots \ldots \ldots \ldots . .50$

3 to 4 ft. ............... 75

\section{AMYGDALUS. Almonds.}

A. nana alba plena (Double Whiteflowering Almond). 5 feet, white, May. Very attractive in the spring when it produces a profusion of showy, double, rose-like flowers.

Each

2 to 3 ft. $\ldots \ldots \ldots \ldots \ldots \ldots \ldots \ldots \$ \$ .50$

3 to 4 ft. .............. .75

A. nana rosea plena (Double Pinkflowering Almond). 5 feet, pink, May. In habit, same as above.

2 to 3 ft. ............ ${ }^{\text {Each }}$

3 to 4 ft. $\ldots \ldots \ldots \ldots \ldots \ldots \ldots . .75$

\section{ARALIA. Angelica Tree.}

A. pentaphylla (Five-leaved Aralia). 7 feet. A good upright growing foliage shrub with glossy deep green leaves.

Each

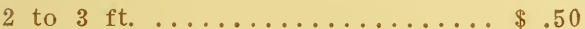

3 to $4 \mathrm{ft} . \ldots \ldots \ldots \ldots \ldots \ldots \ldots \ldots . .75$

A. Spinosa (Hercules Club), 18 feet, greenish white, July. A peculiar native plant with thick, spiny stems producing very large panicles of whitish flowers at the end of the stems. Its huge pinnate leaves give it a very tropical effect.

Each

2 to $3 \mathrm{ft} . \ldots \ldots \ldots \ldots \ldots \ldots \ldots \ldots \$ \ldots$

3 to $4 \mathrm{ft} . \ldots \ldots \ldots \ldots \ldots \ldots \ldots . .75$

\section{BERBERIS. Barbery.}

B. Hackadata. 5 feet. A new vigorous growing sort with good dark green foliage.

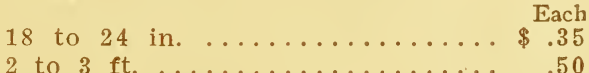

B. Thumbereil (Japanese Barberry). 4 feet. One of the most hardy and valuable of our common shrubs. Dwarf in habit. It makes a splendid specimen, groups well with other shrubs, and as a low hedge plant it has no rival. It has a pleasing green foliage which turns to a bright crimson with the early frosts and finally to a rich yellow as the foliage begins to drop. It bears a profusion of large, solitary, crimson berries which remain fresh and plump on the bushes over winter.

Each Per 10 18 to 24 in. ......... \$ $.35 \$ 3.00$ 2 to $3 \mathrm{ft} . \ldots \ldots \ldots \ldots \ldots . .50 \quad 4.00$

B. vulgaris (Common Barberry). 6 feet, yellow, May. A sturdy upright growing shrub bearing profuse clusters of yellow flowers in the early spring which are followed by scarlet berries which remain on the plants over winter. 2 to 3 Each Per 10 $\$ .50 \$ 3.00$ 3 to 4 ft. ........... $.75 \quad 4.00$

B. vulgaris purpurea (Purple Barberry). 6 feet, yellow, May. A form of the Common Barberry having purple foliage.

18 to 24 in. $\ldots \ldots \ldots \ldots \ldots \ldots \ldots \$ \ldots .35$

2 to $3 \mathrm{ft} . \ldots \ldots \ldots \ldots \ldots \ldots \ldots \ldots . . . . . .50$

\section{BUDDLIEA. Summer Kilac.}

B. variabilis (Butterfly Bush). 5 feet, lilac, late summer. A handsome new species from Thibet. The flowers are produced in dense terminal panicles six inches long.

Strong plants, 50 cents each. 
CALYCANTHES. Sweet Shrub.

C. floridus (Strawberry Shrub). 5 feet, red-brown, all summer. A favorite old-garden shrub with large, glossy deep green leaves.

18 to 24 in. ............. $\$ .4 n$ 2 to $3 \mathrm{ft} . \ldots \ldots \ldots \ldots \ldots \ldots \ldots$

\section{CEPIIIANTHES.}

C. occidentalis (Button Bush). 5 feet. white. July to September. A hardy vigorous shrub with large glossy foliage. Good for massing in moist places.

2 to $3 \mathrm{ft.}$ Each 3 to $4 \mathrm{ft} . \ldots \ldots \ldots \ldots \ldots \ldots \ldots \ldots \ldots$ \%

\section{CHIONANTHES.}

C. virginica (White Fringe), 10 feet, white, May. A large and very ornamental shrub, producing many fragrant fringe-like flowers in large racemes.

Each

2 to 3 ft. $\ldots \ldots \ldots \ldots \ldots \ldots \ldots \ldots$

\section{CTETHRA. Pepper Bush.}

C. alnifolia (Sweet Pepper Bush). 4 feet, white. July, to September. An upright, slow growing. native woodsplant thriring best in damp. shady places. Flowers in long terminal racemes.

2 to 3 ft. $\ldots \ldots \ldots \ldots \ldots \ldots \ldots \ldots \$ .75$

\section{COTITIEA.}

C. arborescens (Bladder Senna). 8 feet, reddish yellow, July. A large shrub of compact growth with small light green compound leaves and pea shaped flowers.

9 to 3 ft $\ldots \ldots \ldots \ldots \ldots \ldots \ldots \ldots \ldots$

3 to $4 \mathrm{ft} . \ldots \ldots \ldots \ldots \ldots \ldots \ldots . .75$

\section{CORNUS. Dogwoods.}

C. alba Siberica (Red Osier). 8 feet. cream, June. A very good shrub with dark green foliage and blood-red branches. Covered with clusters of pure white berries in the fall.

Each Per 10

3 to $4 \mathrm{ft} . \ldots \ldots \ldots \ldots \ldots \ldots . .75 \quad 5.00$

C. florida (Flowering Dogwood). 20 feet, white, May. A small tree or large shrub with spreading branches and large showy flowers.

to 3 ft. $\ldots \ldots \ldots \ldots$ Each

to 8 ft. ............... $\$ 1.00$

C. paniculata (Gray Dogwood). 6 feet, white, July. A very attractive native plant, a dense upright grower with slender gray twigs.

2 to $3 \mathrm{ft.}$ Each Per 10

3 to 4 ft. ........... $.75 \quad 5: 00$
C. Sanguinea (European Red Osier). 8 feet, white, June. Dark green foliage, reddish purple branches, berries black in dense flat-topped clusters.

Each Per 10 2 to $3 \mathrm{ft} . \ldots \ldots \ldots \ldots \ldots \ldots \$ \ldots 0 \% 4.00$

3 to 4 ft. ............ .75 5.00

C. sericea (Silky Cornel). \& feet, white, June. Bark grayish purple, fruits in clusters of pale blue berries. Each Per $1 A$ $3 \mathrm{ft.} \ldots \ldots \ldots \ldots \ldots \ldots \$ .50 \$ 4.00$ 3 to $4 \mathrm{ft} . \ldots \ldots \ldots \ldots \ldots \ldots, \quad .75 \quad 5.00$

C. stolonifera (Wild Red Osier). 6 feet, white, June. A common native shrub with purplish red branches and white fruits.

Each Per 10 3 to $4 \mathrm{ft} . \ldots \ldots \ldots \ldots \ldots . .75 \quad 5.00$

C. stolonifera flaviramea (Goldenbarked Dogwood). A form of the above having bright yellow twigs.

2 to 3 ft ........ Each Per 10

3 to $4 \mathrm{ft} . \ldots \ldots \ldots \ldots \ldots \ldots+1.00 \quad 7.50$

\section{CORYFUS, Hazels.}

C. americana (Hazelnut). 8 feet. A native shrub with numerous upright hranches and dark green foliage.

Each Per 10 2 to $3 \mathrm{ft} . \ldots \ldots \ldots \ldots \ldots \$ .50 \$ 4.00$

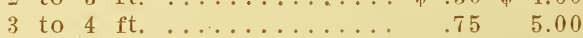

C. avellena purpurea (Purple-leaved Filbert). 6 feet. The best purple-leaved shrub. A spreading shrub, good for massing.

Each

3 to 4 ft. $\ldots \ldots \ldots \ldots \ldots \ldots \ldots \ldots \ldots \ldots \ldots \ldots \ldots \ldots \ldots \ldots$

\section{CYDONIA.}

C. japonica (Japanese Quince). 6 feet, scarlet, May. A thorny shrub with dark green leaves and masses of very showy flowers in the spring before the leaves are out. Good as a hedge plant or for massing.

Each Per 10

18 to 24 in. ........... \$.40\$3.50

2 to $3 \mathrm{ft} . \ldots \ldots \ldots \ldots \ldots . .50 \quad 4.00$

\section{DEUTZIA.}

D. aracilis (Slender Deutzia). 3 feet, white, May and June. A most useful and hardy dwarf shrub, round and dense in growth; flowers numerous and fragrant, produced in small racemes on arching branches.

Each Per 10

12 in. ............. \$.50 \$ 4.00

12 to 18 in. .............. $.75 \quad 5.00$

18 in. bushy $\ldots \ldots \ldots \ldots \ldots$ 
D. Lemoinei (Lemoine's Deutzia). 4 feet, white, June. A vigorous grower, flowers extra large.

18 to 24 in. ......... $\$ .50 \$ 4.00$

2 to 3 ft. ........... $.75 \quad 5.00$

D. scarbra crenata (Double-flowered Deutzia). 6 feet, white tinged rose, June. Tall and a rapid grower. Very apt to winter-kill.

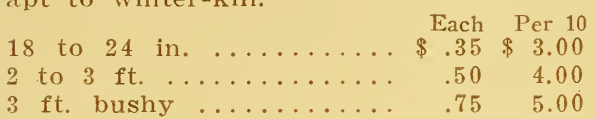

D. scarbra Pricle of Rochester.. $\&$ feet, white, June. A vigorous grower and profuse bloomer, but not overly hardy.

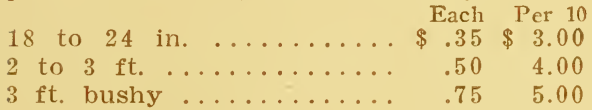

\section{DIERVIIMA. Weigelia.}

D. candida (White Weigelia). 8 feet, white, June and July. A vigorous, erect, bushy grower, the only sort with pure white flowers.

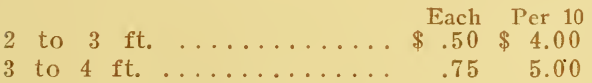

D. hybrida Eva Rathke (Coral Weigelia). 5 feet, crimson, June and July. An erect grower and continuous bloomer. The best red Weigelia.

2 to 3 ft. Each Per 10

3 to $4 \mathrm{ft} . \ldots \ldots \ldots \ldots \ldots . \quad .75 \quad 5.00$

D. rosea (Pink Weigelia). 6 feet, pink, June. A strong symmetrical grower with good foliage. Blooms profusely.

2 to 3 ft. Each Per 10

3 to $4 \mathrm{ft} . \ldots \ldots \ldots \ldots \ldots \ldots \quad .75 \quad 5.00$

\section{ELEAGNUS. Oleaster.}

E. angustifolia (Russian Olive). 12 feet, yellow, June. A large shrub with silvery, often thorny, branches and graygreen foliage. Flowers very showy and fragrant, berries yellow.

2 to 3 ft. $\ldots \ldots \ldots \ldots \ldots \ldots \ldots \ldots \$ \ldots \ldots$

3 to 4 ft. ................ .75

E. longipes (Japanese Oleaster). 6 feet, light yellow, April and May. A very desirable and nearly evergreen shrub with silvery green foliage, fragrant flowers, and bright red edible fruit.

2 to $3 \mathrm{ft} \ldots \ldots \ldots \ldots \ldots \ldots \ldots \ldots \ldots$

\section{EUONYMOUS.}

E. alatus (Winged Strawberry-bush). 6 feet. A spreading compact grower with a peculiar corky growth of bark along the branches. The foliage turns a brilliant crimson in the autumn. Berries numerous, scarlet, very ornamental.

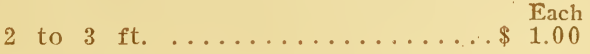

3 to $4 \mathrm{ft} . \ldots \ldots \ldots \ldots \ldots \ldots \ldots . \ldots .25$

E, americanus (Strawberry-bush). 8 feet. An upright shrub with good foliage and a profusion of scarlet berries in the fall.

3 to 4 ft. $\ldots \ldots \ldots \ldots \ldots \ldots \ldots \ldots \ldots \ldots \ldots \ldots$

E. enropaens (Burning Bush). 12 feet. A small tree or large shrub, much resembling the Strawberry-bush.

3 to 4 ft . Each

\section{EXOCHORDA.}

E. grandiflora (Pearl Bush). 8 feet, white, May. A very handsome and showy shrub while in bloom, but a rather loose grower. Flowers in racemes, large and numerous.

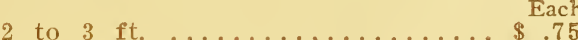

3 to 4 ft. $\ldots \ldots \ldots \ldots \ldots \ldots \ldots \ldots 1.00 \ldots$

\section{FORSYTHA. Golden Bell.}

F. intermedia (Hybrid Golden Bell). 8 feet, yellow, April. An upright grower with slender arching branches. A free bloomer.

Each Per 10

2 to $3 \mathrm{ft} . \ldots \ldots \ldots \ldots \ldots . \$ .50 \$ 4.00$

3 to $4 \mathrm{ft} . \ldots \ldots \ldots \ldots \ldots \ldots \ldots . .75 \quad 5.00$

F. suspensa (Drooping Golden Bell). 6 feet, yellow, April. A drooping shrub, almost a vine. A very free bloomer. Good for hanging over walls and banks.

Each Per 10 $\$ .50 \$ 4.00$

F. suspensa Fortunei (Fortune's Golden Bell). 8 feet, yellow, April. An upright form of Forsythia suspensa.

Each Per 10 $\$ .50 \$ 4.00$

F. viridissima (Upright Golden Bell). 8 feert, yellow, April. Somewhat resembles Fortune's Golden Bell but is a more vigorous bushy grower and the twigs are much greener.

Each Per 10

2 to 3 ft. ........... \$.50\$ $\$ .00$

3 to $4 \mathrm{ft}, \ldots \ldots \ldots \ldots \ldots, \quad .75 \quad 5.00$

\section{HALESIA.}

H. tetraptera (Snowdrop Tree or Silver Bell). 10 feet, white, May. A tall shrub with drooping branches bearing a profusion of large bell-shaped flowers.

Each 


\section{HAMAMELIS. Witch Hazel.}

II. virginiana (Common Witch Hazel). 8 feet, yellow, November. A tall open growing native woods-shrub, valued for its fall bloom.

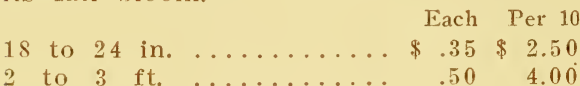

IIBISCUS. Althaea.

II. syriacus (Rose of Sharon). 10 feet, various, August and September. A hardy plant with dense erect growth, blooming freely in the late summer at a time when but few other shrubs are in blossom. The flowers are large, often 4 inches across, in colors ranging from purple through red to white. They are very desirable for hedge plants. We offer the following choice rarieties:

Implissima-double red.

Inemonaeflorus-double rose.

Coelestis - single blue.

Jeamne d' Arc-double white.

Ionstrosus-double white.

liubis-single red.

Snowdrift-single white.

Totus Albus single white.

Each Per 10

2 to 3 ft. $\ldots \ldots \ldots \ldots \ldots \ldots \$ .50 \$ 4.00$

3 to $4 \mathrm{ft} . \ldots \ldots \ldots \ldots \ldots . .75 \quad 6.00$

Tree form, 4 to $5 \mathrm{ft} . . . .1 .00$

\section{HNDRANGEA.}

1f. arborescens sterilis (Hills of Snow) 6 feet, white, June and July. New. A form of the native Hydrangea, erect in growth, especially desirable for planting in shady places. Flowers borne very profusely in large flat clusters.

Each Per 10 2 to $3 \mathrm{ft} . \ldots \ldots \ldots \ldots .50 \$ 4.00$ 3 to $4 \mathrm{ft} . \ldots \ldots \ldots \ldots \ldots . \quad .75 \quad 6.00$

H. paniculata grandiflora (Great Panicled Hydrangea). 7 feet. white, July to September. Probably the most popular summer blooming shrub in cultivation at the present time. Blooms freely, producing large pyramidal panicles of flowers that cover the plant. Each Per 10 2 to $3 \mathrm{ft} . \ldots \ldots \ldots \ldots \ldots \ldots .50 \$ 4.00$ 3 to $4 \mathrm{ft} . \ldots \ldots \ldots \ldots \ldots . .75 \quad 5.00$ Tree form, 4 to $5 \mathrm{ft} . \ldots .1 .00$

\section{KERRIA. Globe Flower.}

K. japonica (Japanese Globe Flower). 6 feet, bright yellow, June. A most graceful drooping shrub with yellowgreen leaves and bright green twigs which are especially attractive in winter. It produces many large showy flowers.

18 to 24 in $\ldots \ldots \ldots \ldots \ldots \ldots \ldots .50$

2 to 3 ft. ............. .75

\section{LIGUSTRUM. Privets.}

A group of ornamental shrubs very desirable for hedging purposes. For the varieties not listed here see Hedge Plants: page 26.

I. ibota Regalianum (Regal's Privet) 5 feet. A very desirable form both for massing and hedging. The branches are very dense and twiggy and droop attractively. The leaves are small and of a very good dark green.

18 to 24 in Each Per 10 $.50 \$ 4.00$ 2 to 3 ft. ........... .75 6.00

\section{LONICERA. Honeysuckles.}

I. Momowi (Morrow's Honeysuckle). 6 feet, white, May and June. Upright and dense in growth. Flowers freely and is covered with bright red fruit in August and September.

Each Per 10 $\$ .50 \$ 4.00$

3 to $4 \mathrm{ft} . \ldots \ldots \ldots \ldots \ldots . .75 \quad 5.00$

I. tatarica (Tartarian Honeysuckle) 12 feet, pink to white, May and June. A sturdy grower with upright branches. Small fragrant flowers followed by red or orange berries.

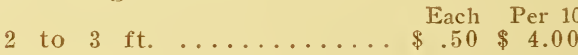

3 to $4 \mathrm{ft} . \ldots \ldots \ldots \ldots \ldots . .75 \quad 5.00$

\section{PHILADERPHUS. Syringa.}

P. coronarius (Garland Syringa or Mock Orange). 12 feet, white, May to June. A hardy shrub with upright arching branches. Flowers very fragrant and borne in great profusion.

Each Per 10

3 to $4 \mathrm{ft} . \ldots \ldots \ldots \ldots \ldots . .75 \quad 5.00$

P. coronarius aureus (Golden Sylihga) 5 feet, white, May and June. A compact $\cdot$ shrub with brilliant yellow foliage.

Each

18 to 24 in. ............ \$ .50

2 to $3 \mathrm{ft} . \ldots \ldots \ldots \ldots \ldots \ldots \ldots \ldots \ldots \ldots \ldots \ldots . .75$

P. Lemoinei (Lemoine's Syringa). 5 feet white, May. Branches slender and arching; flowers very fragrant, in large clusters.

Each Per 10 2 to 3 ft. ........... \$ $.75 \$ 5.00$

P. Lemoinei Aralanche. 4 feet, white, May and June. A more erect form than the type.

Each Per 10

P. grandiflorus (Large-fowered Syringa). 15 feet, white, May and June. A vigorous growing upright shrub with large leaves and large showy flowers.

Each Per 10

2 to 3 ft. .......... \$ .50 $\$ 4.00$

3 to 4 ft. $\ldots \ldots \ldots \ldots \ldots . \quad .75 \quad 5.00$ 


\section{PIRUNUS. Plum.}

P. triloba (Double-flowering Plum). 6 feet, rose, May. An upright vigorous grower. The flowers, which are often an inch in diameter, completely cover the slender branches.

2 to 3 ft. .............. \$ $\$ 50$

3 to 4 ft. ................ 75

\section{PTELEA.}

P. trifoliata (Hop Tree). 15 feet. A large shrub or small tree of rapid growth and robust habit. Fruit winged and borne in clusters.

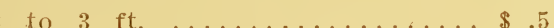

3 to $4 \mathrm{ft} . \ldots \ldots \ldots \ldots \ldots \ldots \ldots . .75$

\section{MIIIMNES.}

- R. catharticus (Common Buckthorn). 12 feet. A hardy vigorous shrub with dark green foliage, often used for hedging.

2 to $3 \mathrm{ft} \ldots \ldots \ldots \ldots \ldots \$ \ldots 0^{\text {Each }}$ Per 10

\section{RIIODO'TYPOS.}

12. kerroides (White Kerria). 5 feet, white, May and June. A very ornamental shrub with handsome foliage and large solitary flowers followed by shinning black fruits which remain on the plant over winter.

Each

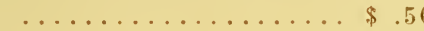

3 to $4 \mathrm{ft} . \ldots \ldots \ldots \ldots \ldots \ldots \ldots . .75$

RHUS. Sumac.

1. aromatica (Fragrant Sumac). 3 feet, yellow, May. A native spreading shrub, almost a vine. The flowers appear before the leaves in the spring and are followed by bright red fruits. Excellent for covering dry, sandy, or rocky banks and for massing with other shrubs.

2 to 3 ft. ............. .50

3 to $4 \mathrm{ft} . \ldots \ldots \ldots \ldots \ldots \ldots \ldots . .75$

R. copallina (Shining Sumac). 5 feet, yellow-green, July and August. Charming dark green leaves which are very brilliant in the autumn. Succeeds well in dry places.

Each

18 to 24 in. $\ldots \ldots \ldots \ldots \ldots \ldots \ldots \ldots \$ .35$

2 to $3 \mathrm{ft} . \ldots \ldots \ldots \ldots \ldots \ldots \ldots . .50$

R. cotinus (Purple Fringe or Smoke Tree). 10 feet, yellow-green, June. A large shrub forming a broad rounded head. Leaves very broad and light green. The flower are produced very freely on long loose panicles which entirely cover the plant. The purple flower stalks give the plant a. smoky appearance after the petals have fallen.

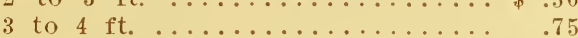

12. glabra (Smooth Sumac). 15 feet The common wild Sumac. Leaves very large and compound. Fruits in very harge showy crimson clusters in the autumn. Very good for wild mass planting.

Each Per 10

2 to $3 \mathrm{ft} . \ldots \ldots \ldots \ldots \ldots \ldots .25 \$ 2.00$

3 to $4 \mathrm{ft} . \ldots \ldots \ldots \ldots \ldots . .35 \quad 3.00$

4 to $5 \mathrm{ft} . \ldots \ldots \ldots \ldots \ldots . .50 \quad 4.00$

1. typhina laciniata (Fern-leaved Sumac). 10 feet. A variety with velvety branches and very deeply cut fernlike leaves.

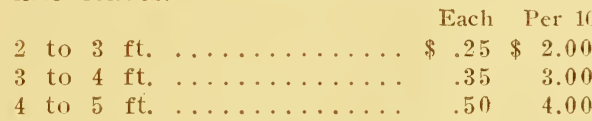

\section{IIIBES.}

12. alpinmm (Mountain Currant). 3 feet, yellow, May. A dense upright growing shrub with deep green foliage and fragrant flowers.

Each

2 to $3 \mathrm{ft} . \ldots \ldots \ldots \ldots \ldots \ldots \ldots \$ .50$

li. aureum (Yellow-flowered or Missouri Currant). 6 feet, yellow, May. A native species with smooth. shining foliage, fragrant flowers, and black fruit.

2 to 3 ft. $\ldots \ldots \ldots \ldots \ldots \ldots \ldots \ldots \$ .50$

so $4 \mathrm{ft}, \ldots \ldots \ldots \ldots \ldots \ldots \ldots \ldots, .75$

\section{SMIBICUS, EIder.}

S. nigra aurea (Golden Elder). 8 feet, white, July. A vigorous spreading shrub with golden yellow foliage when planted in the full sun.

Each Per 10 2 to $3 \mathrm{ft} . \ldots \ldots \ldots \ldots \ldots . \$ \ldots 0 \$ 4.00$ 3 to 4 ft. $\ldots \ldots \ldots \ldots \ldots . .75 \quad 5.00$

S. nigra laciniata (Cut-leaved Elder). 6 feet, white. June. A variety with deep green foliage variously cut and incised.

Each Per 10 3 to $4 \mathrm{ft} \ldots \ldots \ldots \ldots \ldots . .75 \quad 5.00$

S. racemosa (Red-berried Elder). feet, white, May. A coarse shrub with deep green foliage and red berries that ripen early.

Each Per 10

2 to $3 \mathrm{ft} . \ldots \ldots \ldots \ldots \ldots \$ .50 \$ 4.00$

3 to $4 \mathrm{ft} . \ldots \ldots \ldots \ldots \ldots . .75 \quad 5.00$ 


\section{HARDY GARDEN ROSES.}

Our Roses are strong plants, grown out of doors, well rooted, and in every way first class. They have already; bloomed before being sent out and are in every respect much better and stronger plants than the ones that are so freely advertised and sent out by mail, which are small tender shoots started in a greenhouse and sent out before they have established growth and constitution enough to stand the shock of transplanting. All roses furnished are 2 year old field grown stock.

Roses require full sun, plenty of protection, and a rich, well drained soil.

Except where otherwise noted, any of the Roses in the following list will be furnished at 50 cents each; $\$ 4.50$ per 10 .

\section{HYBRID PERPETUAL ROSES.}

Alfred Colomb-Very large, globular, of a bright cherry red.

Anne de Diesbach-Very large, a clear, bright carmine pink.

Baron de Bonstettin-A large, deep velvety maroon Rose.

Eugene Furst-Blossoms large, crimson with shadings of deep black.

Fisher Holmes-Very large flowers of a deep velvety crimson.

Frau Karl Druschki (Snow Queen) Pure white, the best white Hybrid Perpetual.

General Jacqueminot-A well known and desirable rose, a deep rich velvety crimson in color.

Magna Charta-Bright pink suffused with carmine.

Marshall P. Wilder-A large well formed and very fragrant Rose of a rich carmine red color.

Mrs. John Laing-Very fragrant, one of the best pinks.

Paul Neyron-A very desirable Rose, very large and fragrant, dark rose.

Prince Camille de Rohan-A splendid large Rose, the nearest approach to a black.

Ulrich Brumner-Flowers large and full, of a bright cherry red.

\section{HARDY CLIMBING ROSES.}

American Pillar-Unquestionably one of the finest single roses known; extremely hardy, of rapid growth, and a profuse bloomer. Flowers rich pink with white centers.

Baltimore Belle-One of the hardiest climbers, a handsome double white.

Climbing American Beauty-A new climber of rare beauty, very hardy and a strong grower. The flowers are very large, borne on long stems, of a deep rosy carmine shading toward deep crimson. Blooms very freely during May and June and quite often during the summer.

$$
2 \text { year plants, } \$ 1.00 \text { each }
$$

Dorothy Perkins-One of the best of the climbers. Flowers large for a Rose of this class and of a beautiful shell pink.

Excelsa (Red Dorothy Perkins). Flowers in large trusses, very double, crimson maroon.

Tausendschon-Flowers a very delicate pink, produced in large trusses, a very profuse bloomer.

White Dorothy Perkins-A whiteflowered form of the well known and much prized Dorothy Perkins.

\section{RAMBLER ROSES}

Crimson Rambler-A perfectly hardy climber that will grow anywhere. During the blooming season it is covered with large clusters of crimson flowers.

Flower of Fairfield-An ever-blooming counterpart of the Crimson Rambler except that the flowers are much more brilliant.

Queen of the Prairies-Flowers a deep rosy red, often with a white stripe.

Yellow Rambler-Semi-double, yellow in the bud but white when fully open.

Baby Ramblers-A type of Roses which is very popular for bedding purposes. They form shapely, compact. bushy specimens about 18 inches high and produce immense trusses of small flowers in great profusion from early in the season until severe frosts. We can furnish them in white, pink, and crimson.

\section{MOSS ROSES.}

Perfectly hardy anywhere. The beauty of the flower lies in the delicate mossy covering which surrounds the bud and gives the opening flower a unique appearance.

Glory of Mosses-Pink tinged crimson

Henri Martin-Delicate pink, a profuse bloomer.

White Bath-Large, pure white. 
YELLOIY ROSES.

Persian Yellow-Very showy bright yellow flowers of medium size.

Harrison's Yellow-Golden yellow, medium size, semi-double; a freer bloomer than the Persian.
TREE ROSES.

These are Roses top grafted on stems about foul feet high which give them the appearance of small trees. We offer extra strong Holland grown trees in white, pink, red and yellow. $\$ 1.00$ each

\section{IROSA-SPECIES OF ROSES.}

R. blanda (Meadow Rose). 5 feet, pink, June. An erect shrub with reddishpurple branches armed with slender prickles. Flowers large. single and showy.

Each Per 10 2 yr. vlants ......... \$ $.35 \$ 2.50$

R. carolina (Carolina Rose). 6 feet, pink. July and August. Upright in growth with numerous branches armed with hooked spines. Flowers single, two inches across, in flat-topped clusters.

Each Per 10

2 yr, plants ......... \$ $.35 \$ 2.50$

12. lucida ((xlossy Rose). 4 feet. pink. May and June. A low spreading shrub with shining dark green foliage and single flowers in clusters. 2 yr. plants $\ldots \ldots \ldots \ldots \ldots \$ \$ .35 \quad \begin{aligned} & \text { Each } \\ & \$ 2.50\end{aligned}$

R. multiflora (Japanese Climbing Rose). 6 feet, white, June. Branches spreading and recurving, inclined to climb. Flowers single, borne very profusely in pyramidal clusters.

2 yr. plants ............ Each

R. Mubixinoma (Sweet Brier). 10 feet, pink, June. A dense growing species with showy single flowers and scarlet fruit.

y. Each
1R. rubifolia (Red-leaved Rose). 5 feet, pink. June. An open growing species with purplish sttems and red leaves. Flowers single, fruit scarlet.

Each 2 yr. plants ............\$.50

R. mgosa (Ramanas Rose). 5 feet, red or white, May and September. An upright hardy shrub with .upright stems thickly set with thorns. Flowers single, very large and showy; fruit very large and of a brilliant scarlet.

Each Per 10

2 vr. plants $\ldots \ldots \ldots \ldots . \$ .50 \$ 4.00$ To color ........... $.75 \quad 6.00$

IR. setigera (Prairie Rose). 6 feet, deep rose. June and July. A slender shrub with long recurving branches excellent for planting along banks. Flowers single, about two inches across, in clusters.

R. wichmiana (Memorial Rose). White, July and September. A semievergreen shrub with prostrate creeping branches and glossy green foliage. Flowers single, about two inches across in elusters.

2 yr. plants $\ldots \ldots \ldots \ldots \ldots \ldots \$ \$ .50$

\section{ROBSINII.}

li. hispida (Rose Acacia) . 5 feet, rose, May and June. A low shrub with hairy branches and leaves and showy flowers in loose clusters. Will grow in almost any soil.

Each Per 10

2 to $3 \mathrm{ft}, \ldots \ldots \ldots \ldots \ldots \ldots .50 \$ 4.00$

3 to $4 \mathrm{ft} . \ldots \ldots \ldots \ldots \ldots . \quad .75$

\section{SPIIR.AE.I.}

S. axuta. 5 feet, white, May. Foliage dense, light green. Flowers in manyflowered clusters along drooping slender branches.

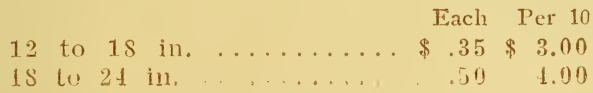

S. Billardi. 6 feet, bright pink, July and August. Upright in habit with red-brown branches, dull green foliage and dense spikes of flowers about six inches long.

Each Per 10 18 to 24 in. $\ldots \ldots \ldots \ldots \ldots \ldots \$ .35 \$ 3.00$ 2 to 3 it. .......... $.50 \quad 4.00$

S. Billardi alba. A white flowered form of the above.

is to 24 Each Per 10 2 to $3 \mathrm{ft} . \ldots \ldots \ldots \ldots \ldots . .50 \quad .50$

S. bumalda. 3 feet, light pink, July and August. A compact low-growing shrub with good dense foliage. Flowers in showy flat clusters borne on erect stems. Excellent for massing in front of taller shrubs.

is lo 24 in.

Each Per 10 $\$ .50 \div 4.00$ 
S. bumalda Anthony Waterer. 3 feet, bright crimson, July and August. A much improved form of the preceeding with flowers of a darker red.

Each Per 10

12 to 18 in. .......... \$.50\$ $\$ 4.00$

18 to 24 in. .............. $75 \quad 6.00$

S. bumalda Margurieta. 3 feet, July and August. A new form of S. bumalda having magenta flowers.

Each Per 10 12 to 18 in. .......... \$.50 \$ 4.00 18 to 24 in. ................ 75 6.00

S. callosa alba. 2 feet, white, June to September. One of the best dwarf shrubs, bushy and symmetrical.

Each Per 10

12 to 18 in. ......... \$.35\$3.00

18 to $24 \mathrm{in.} \ldots \ldots \ldots \ldots \ldots . .50 \quad 4.00$

S. callosa rosea. 4 feet, light pink, June to September. Upright in growth with dull green leaves and clusters of flowers produced on erect branches.

Each Per 10

18 to 24 in. ......... \$ .35 \$ 3.00

2 to 3 ft. ............... .50 4.00

S. opulifolia (Ninebark). 10 feet, white, June. A strong growing shrub with dull green foliage and spreading branches which tend to droop. Excellent for massing.

Each Per 10

2 to 3 ft. .......... \$.50\$4.00

3 to 4 ft. ............. .75 5.00

S. opulifolia aurea (Golden Ninebark). 10 feet, white, June. A form of the preceeding with bright yellow foliage.

2 to 3 ft. $\ldots \ldots \ldots \ldots \ldots \ldots . .75 \$ 5.00$

S. prunefolia (Bridal W.reath). 6 feet, white, May. Flowers double, in dense racemes along slender upright branches. Leaves plum-shaped and of a dark glossy green.

Each Per 10 2 to 3 ft. .......... \$.50\$ $\$ .00$

S. salicifolia (Willow-leaved Spireá). 6 feet, pink, June and July. A species native to the east with long narrow pointed leaves and flowers in narrow panicles about six inches long.

Each Per 10 18 to 24 in. ......... \$. $35 \$ 3.00$ 2 to 3 ft. ............... .50 4.00

S. sorbifolia (Ash-leaved Spirea). 5 feet, white, June. A very attractive and vigorous species with leaves like those of the Mt. Ash.

Each Per 10

3 to $4 \mathrm{ft} . \ldots \ldots \ldots \ldots \ldots . . .75 \quad 6.00$

S. Thunbergii. 4 feet, white, April and May. One of the best dwarf shrubs. Rounded and graceful in form, branches slender and drooping, foliage narrow, yellowish green and very dense. The first of the Spireas to bloom in the Spring.

12 to 18 in. ........ \$.35 \$ $\$ 3.00$

18 to 24 in........... $.50 \quad 4.00$

Very bushy, 2 to 3 ft. .... $\quad .75 \quad 6.00$

S. Van Houttei (Van Houtte's Bridal Wreath). 7 feet, white, May. One of the best known of the old-garden shrubs. Spreading in growth with arching slender branches and dense light green foliage. At blooming time the plant is practically covered with clusters of flowers.

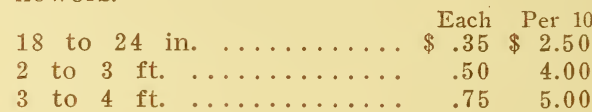

\section{SYMPHORICARPOS.}

S. racemosus (Snowberry or White Waxberry). 6 feet, pink, July. An upright shrub valued for its large white waxy berries which hang on the branches until winter.

Each Per 10 2 to $3 \mathrm{ft} . \ldots \ldots \ldots \ldots \ldots . . \ldots 0 \$ 4.00$ 3 ft., bushy .......... .75 5.00

S. vulgaris (Coralberry, Red Waxberry, or Indian Currant). A pretty drooping shrub with reddish purple berries that hang on the branches all winter.

2 to 3 ft. ........... $\$ .50 \$ 4.00$

3 to 4 ft. $\ldots \ldots \ldots \ldots \ldots \ldots . . .75 \%$

\section{SYRINGA. Lilac.}

S. japonica (Japanese Tree Lilac), 30 feet, white, June and July. Foliage dark green, flowers creamy white and odorless.

2 to 3 ft .................... Each

S. josikaeta (Hungarian Lilac). 10 feet, violet, June. A sturdy vigorous. shrub with stout upright branches, blooming later than the common Lilacs. 2 to 3 ft. ............. $\$ .75$

S. Rothomagensis (Rouen or Persian Lilac). 8 feet, pale lilac, May and June. A cross between the Common Lilac and the true Persian Lilac. Slender arch. ing branches and small foliage. We also offer the white and red forms.

2 to 3 ft. .......... $\$ .50 \$ 4.00$

3 to 4 ft. $\ldots \ldots \ldots \ldots \ldots \ldots . . . . \ldots \ldots$

S. villosa. 10 feet, pink-lilac, May and June. An upright species with stout warty branches and flowers in broad branching panicles.

2 to 3 ft. $\ldots \ldots \ldots \ldots \ldots \ldots \ldots \ldots \ldots \ldots \ldots \ldots$ 
S. vulgaris (Common Lilac). 12 feet, purple, May. The well-known old-fashioned Lilac so common in gardens. It is hardy and vigorous, endures neglect, and blooms abundantly.

Each Per 10

3 to 4 ft. $\ldots \ldots \ldots \ldots \ldots \ldots . .50 \quad 3.50$

4 to 5 ft. .......... $.75 \quad 5.00$

S. vulgaris alba (Common. White Lilac). A white form of the above.

Each Per 10

2 to 3 ft. ................. $\$ 35.00$

3 to $4 \mathrm{ft} . \ldots \ldots \ldots \ldots \ldots . .50 \quad 4.00$

4 to $5 \mathrm{ft} . \ldots \ldots \ldots \ldots \ldots \ldots . .75 \quad 6.00$

S. vulgaris hybrids. They are usually more dwarf than the Common Lilac itself, but far surpass it in form, size, and color of bloom. We offer the following varieties.

2 to $3 \mathrm{ft} . \ldots \ldots \ldots \ldots \ldots \ldots \ldots \ldots \$ \ldots .75$

Alphonse Lavelle-Very large, single, blue shading to violet.

Bertha Dammon-Large single white.

Charles $\mathbf{X}$.- Single, large loose trusses of reddish purple flowers.

Lndwig Spaeth-Single, large, dark purplish red.

Marie LeGrave-Plant rather dwarf, flowers large, one of the best single white Lilacs.

Marie Temoine-A superb double white flower.

M. Cassimir Perier-Very large double white.

Michael Buckner-Very double pale lilac.

Sen. Volland-Large double red.

\section{TAMARIX.}

T. africana (African Tamarisk). 10 feet, pink, April and May. A pretty shrub with fine, feathery, light green foliage and large racemes of closely set small flowers.

Each Per 10

2 to 3 ft. .......... $\$ .50 \$ 4.00$

3 to $4 \mathrm{ft} . \ldots \ldots \ldots \ldots \ldots \ldots . .75 \quad 5.00$

\section{VIBURNUM.}

V. acerfolium (Maple-leaved Viburnum). 5 feet. A low-growing woodsshrub good in shady places.

18 to 24 in. .......... $\$ .50 \$ 4.00$
V. dentatum (Arrow Wood). 8 feet. One of the best shrubs for massing for foliage effect.

Eacl

2 to $3 \mathrm{ft} . \ldots \ldots \ldots \ldots \ldots \ldots \ldots \$ .50$

3 to $4 \mathrm{ft} . \ldots \ldots \ldots \ldots \ldots \ldots \ldots \ldots . .75$

V. lantana (Wayfaring Tree). 10 feet, white, May and June. A pretty foliage shrub with stout upright branches and large heads of flowers followed by showy clusters of bright red fruit.

4 to $5 \mathrm{ft} \ldots \ldots \ldots \ldots \ldots \ldots \ldots$

V. lentago (Sheepberry). 10 feet. white, May and June. Foliage a light glossy green, flowers very fragrant. A native shrub which is very good for mass planting.

Each

2 to 3 ft. $\ldots \ldots \ldots \ldots \ldots \ldots \ldots \ldots .50$

3 to $4 \mathrm{ft} . \ldots \ldots \ldots \ldots \ldots \ldots \ldots \ldots . .75$

V. opulus (High Bush Cranberry). 8 feet, white, May and June. Upright and spreading in growth. The clusters of decorative fruit begin to color about the first of July and remain on the branches and keep their bright scarlet color until the next spring.

Each Per 10

2 to 3 ft. $\ldots \ldots \ldots \ldots \ldots \ldots \$ .50 \$ 4.00$

3 to $4 \mathrm{ft} . \ldots \ldots \ldots \ldots \ldots . .75 \quad 5.00$

V. opulus sterilis (Common Snowball or Guelder Rose). 8 feet, white, May and June. A form of the above in which all of the flowers are showy and sterile.

2 to Each Per 10 .............. $\$ .50 \$ 4.00$

3 to $4 \mathrm{ft} . \ldots \ldots \ldots \ldots \ldots \ldots, \quad .75 \quad 6.00$

V. prunefolium (Black Haw or Stagger Bush). 12 feet, white, May and June. Smooth glossy foliage and black fruits.

2 Each Per 10

3 to 4 ft. .......... $\$ .50 \$ 4.00$

V. tomentosum plicatum (Japan Snowball). 8 feet, white, June. Large, rough, dark green leaves and globose flower clusters that are over three inches across. It has better foliage and whiter flowers than the Common Snowball.

Each

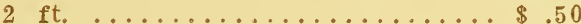

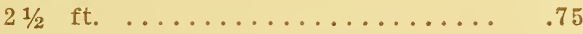




\section{HEDGE PLANTS}

Plants sold for hedging purposes are, as a rule, not as bushy for their height as are plants sold for individual planting and for this reason are quoted at a lower price than are selected specimens.

BERBERIS Thumbergii. (Thunberg's Barberry). 4 feet. The best deciduous dwarf plant for either formal or informal hedging. It stands trimming well, but probably makes a more pleasing hedge when allowed to grow naturally. The foliage is a pleasing green, turning to a bright crimson in the Fall. Per 10 Per 100 12 to 18 in. ........\$1.50 $\$ 10.00$ 18 to 24 in. ........... 2.5020 .00

B. vulgaris (Common Barberry). 6 feet. A sturdy erect grower with light green leaves.

Per 10 Per 100 12 to $18 \mathrm{in} \ldots \ldots \ldots \ldots \ldots \$ 1.00 \$ 8.00$ 18 to 24 in. ........... $1.50 \quad 10.00$

B. vulgaris purpurea (Purple-leaved Barberry). 6 feet. A purple leaved form of the above. $\ldots \ldots \ldots \$ 1.00 \$ 8.00$ 18 to 24 in. .......... $1.50 \quad 10.00$

LIGUSTRLM ammense (Hardy Amoor River Privet). 10 feet. Very dense and upright in growth, especially when pruned. Foliage a good dark green.

Per 10 Per 100

12 to 18 in $\ldots \ldots \ldots \ldots .00 \$ 8.00$

18 to 24 in. .......... $2.00 \quad 12.50$

2 to $3 \mathrm{ft} . \ldots \ldots \ldots \ldots \ldots 3.00 \quad 18.00$

T. ibota regalianum (Regal's Privet). 5 feet. A low growing, spreading form, making an especially fine informal hedge.

Per 10 Per 100

12 to 18 in. .......... $\$ 3.00 \$ 25.00$

18 to 24 in. ........... $4.00 \quad 30.00$
I. ovalifolium (California Privet). 10 feet. Upright and stiff in habit and of very dense growth. Foliage glossy green, tending to be evergreen. Not extremely hardy and very apt to winterkill.

Per 10 Per 100 12 to 18 in. .......... $\$ 1.00 \$ 6.00$ 18 to 24 in. ............. $1.50 \quad 8.00$ 2 to 3 f.t. ............ $2.00 \quad 12.00$

I. polishi (Polish Privet). A new species from Poland, the hardiest of all of the Privets. 10 feet, upright and dense in growth. Foliage a lustrous blue-green, semi-evergreen. Flowers white in large panicles, much larger and more showy than those of any other Privet. An extremely valuable new hedge plant.

Per 10 Per 100

12 to 18 in $\cdots \quad \$ 2.50 \$ 18.00$

18 to 24 in. ......... $3.50 \quad 20.00$

2 to 3 ft. ........... $4.00 \quad 25.00$

MORUS alba tatarica (Russian Mulberry). A small tree forming a very dense tall hedge when pruned.

Per 10 Per 100

12 to 18 in. .......... \$ .30 $\$ 1.00$

18 to 24 in. .......... $.50 \quad 2.00$

2 to $3 \mathrm{ft} . \ldots \ldots \ldots \ldots \ldots . .75 \quad 4.00$

SYRINGA vulgaris (Common Lilac, White or Purple). 12 feet. Hardy and vigorous, forming a dense tall hedge.

Per 10 Per 100

12 to 18 in. ......... $\$ 1.50 \$ 12.00$

18 to 24 in. ............... $2.00 \quad 15.00$

2 to 3 ft. ............ $2.50 \quad 18.00$ 


\section{ORNAMENTAL VINES}

For softening the lines of buildings, for shading verandas and pergolas, for climbing over sheds and fences and other unsightly objects, this class of plants is invaluable. In shaded places and beneath old trees, where grass will not grow, they are often used as ground cover. On steep slopes and banks they prevent erosion. They are almost all strong rapid growers, producing effects much more rapidly than do trees and shrubs.

\section{AC'TINIDIA.}

A. arguta (Silver Vine). A strong growing vine with dark green, lustrous, heart-shaped leaves and noding clusters of white flowers in early summer.

Each 2 yr. plants $\ldots \ldots \ldots \ldots \ldots \ldots \$ .75$

AKEBIA.

A. quinata (Five-leaved Akebia). A graceful hardy climber with twining stems and very handsome foliage.

Each Per 10

2 yr. plants

\section{BOUSSINGAULTIA.}

B. basseloides (Madeira Vine). A popular climber of rapid growth with fleshy, heart-shaped leaves and numerous racemes of feathery flowers.

Heavy bulbs ........... $\$ .25$

\section{CETASTRUS.}

C. scandens (Climbing Bittersweet). A vigorous climber, or twiner, with bright green leaves and showy crimson capsuled fruit in the fall.

$$
\text { Each Per } 10
$$

2 yr. plants .......... $\$ .50 \$ 3.50$

\section{CLEMATIS.}

C. hybrida (Large-flowered Clematis). Graceful free-flowering vines with showy flowers especially adapted for twining on porches, trellises, etc. They require a deep, rich, loamy soil with good drainage. The plants are very susceptible to injury by drought and it is essential that they be placed in moist locations. We offer the following varieties:

Henryi-very large, creamy white.

Jackmani-large rich purple flowers in great profusion. One of the best.

Ramona-large deep sky-blue flowers.

Ville de Lyon-bright red well formed flower's.

Each Per 10

2 yr. plants ....... \$1.00 $\$ 7.00$

C. coccinea (Scarlet Clematis). A very handsome climber bearing thick bell-shaped flowers of a bright coralred.

\section{ARISTOLOCHIA.}

A. sipho (Dutchman's Pipe). A strong growing vine with immense heart-shaped leaves. Grows very well in shady places.

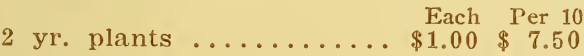

\section{BIGNONIA.}

B. radicans (Trumpet Creeper). A high climbing vigorous vine with stout spreading branches. Flowers orangered in large terminal clusters.

Each Per 10

2 yr. plants ......... \$.35\$2.50

3 yr. plants ........... $50 \quad .50 \quad 4.00$
Each Per 10

2 yr. plants ..........\$ $.50 \$ 4.00$

C. paniculata (Small-flowered Japanese Clematis). A vigorous hardy climber with glossy dark green leaves and fragrant star-shaped flowers produced in great profusion.

2 yr. plants ......... Each $\begin{array}{rr}\text { Per } 10 \\ .50\end{array}$

2 yr. plants, extra strong... $\quad .75 \quad 5.00$

\section{HUMULUS.}

H. lupulus (Hop Vine). A good vine for covering arbors, walls, fences, etc. The young flowers and hops are very fragrant.

Strong plants ............\$ \$ 25 
TONICFR. Moneysuckle.

T. japonica Halliana (Hall's Japan Honeysuckle). A strong grower with deep green foliage which is almost evergreen. Flowers white to yellow, very abundant and fragrant. Very good for ground cover on steep banks.

Each Per 10 2 yr. plants ........\$ \$.50 \$ 4.00

L. sempervirens (Scarlet Trumpet Honeysuckle). Produces clusters of brilliant scarlet flowers throughout the summer. Leaves in pairs, united at the base.

2 vr. plants .........\$ $\$ .50 \$ 4.00$

\section{TYCIUM. Matrimony Vine.}

I. chinense (Chinese Matrimony Vine) A hardy vine, almost a-shrub, with long, slender, drooping branches. Bears purple flowers throughout the summer followed by scarlet fruits. Especially good for holding steep banks.

Each Per 10

2 vr. plants .........\$ \$.50 \$ 4.00

PUERARIA. Kudzu Vine.

P. Thunbergiana. An herbaceous vine of exceedingly rapid growth, often grom- ing 30 or 40 feet in a season. Very useful where an immediate shade is desired.

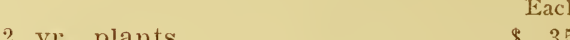

\section{IVISTARIA.}

IV. chinensis (Chinese Purple Wistaria). A heavy strong-growing vine with pale green foliage, producing in May a multitude of long hanging clusters of purple flowers.

2 yr. plants ........ $\$ .35 \$ 2.50$

W. chincnsis alba (Chinese White Wistaria). A white flowered form of the above.

vach Per 10

W. frutescens magnifici (American Wistaria). A smaller, more slender vine than the Chinese, flowering a little later. Flowers lilac-purple.

2 yr. plants $\ldots \ldots \ldots \ldots \ldots \$ \$ .50 \$ 4.00$

IV. multijnga (Loose-clustered Wistaria). Flowers a deep blue in very long, loose clusters. The plant flowers when quite young.

Each 2 yr plants .............\$ \$.50 


\section{HARDY HERBACEOUS PERENNIALS}

Each year shows a marked increase in the popularity of these "old-fashioned" garden flowers. Though especially suited for border planting, either by themselves or in connection with shrubbeiy groups, these plants look well anywhere and will, with comparitively little care, give a succession of bloom from early spring till late frosts. They do well in almost any good garden soil, require little or no cultivation other than enough to keep down the weeds, and appear year after year without having to be replaced. All perennials do best when planted in the early fall.

In the descriptions in the following list we give the approximate height which the plant may be expected to attain at maturity, the month, and the color of the bloom.

Except where other prices are noted, we can furnish good strong plants of any of the perennials in the following list at 25 cents each; $\$ 2.00$ per 10 .

ICHILLEA milfolimm roseum (Rosy Milfoil). 18 inches, all summer, bright pink.

A. ptarmica-The Pearl. 2 feet, all summer, double white.

ALTHAEA rosea (Hollyhock). 2 feet, all color's, both single and double.

ANCHUSA italica-Dropmore variety. (Alkanet). 5 feet, all summer, gentianblue.

ANTHEMIS tinctoria Kelwayii (Hardy Marguerite). 3 feet, June to September, golden yellow.

AQUELEGI canadeusis (Common Columbine). 2 feet, scarlet and yellow, May to July.

A. chrysautha. 3 fret, yellow, May to July.

A. chrysantha alba. 3 feet, white. May to July.

A. coerulea (Rocky Mountain Columbine). 18 inches, blue, May to July.

A. hybrida-Veitch's Long Spurred Hybrids. 2 feet, mixed colors, May to July.

A. vulgaris fl. pl. 2 feet, May to July, white to blue, double.

BELIIS pereunis (English Daisy). 6 inches, all summer, rose and white.

BOCCONIA cordata. 5 feet, July and August, white.

BoLTONIA latisquama. 4 feet, August and September, white.

CAMPANULA carpatica (Carpathian Hair-bell). 9 inches, June to September, white and deep blue.

C. medium (Canterbury Bells). 3 feet blue and white, June and July.
C. persicifolia (Peach Bells). 2 feet. blue and white, June and July.

CHRISANTHEMTIS, Hardy or POMpom. 2 feet, rose, white and yellow, September and November.

CHRYSANTHEMUM lucanthemmu (Shasta Daisy). 18 inches, white, June to September.

CLEMATIS recta, 3 feet, June and July, white and fragrant.

CONVALIARII majalis (Lily-of-theValley). 6 inches, May, white.

COREOPSIS lanceolata spandiflora. 2 feet, June to October, golden yellow.

DELPHINIUM belladona (Larkspur). 2 feet, June and July, sky-blue. 35 cents each; $\$ 3.00$ per 10 .

D. formosmm. 4 feet, June to September, deep blue.

D. Hybridum. 4 feet, June to September, all shades of blue.

DIANTHUS barbatus (Sweet William) 18 inches, May to July, all colors.

D. plumarius (Hardy Pink). 12 inches, May and June, various.

DICENTRA spectabilis (Bleeding Heart). 18 inches, May and June, light pink.

DIGITLLS purpurea (Foxglove). 5 feet, June and July, white to purple.

FUNIKA subcordata grandiflora (Day Lily). 2 feet, September, white and fragrant.

GAILCARDIA grandiflora. 18 inches, May to November, yellow to orange red.

GEUM coccinimm. 18 inches, Jume and July, scarlet. 
HEMEROCALIS hava (Lemon Lily). 2 feet, July and August, orange.

HIBISCUS moscheutos-Crimson Eye (Rose Mallow). 6 feet, August and September, white, pink, or rose, with a deep crimson eye.

IRIS germanica (German Iris). 18 inches, May to July.

Celeste_pale lavendar.

Flavescens-pale yellow.

Florentina alba-pearly white.

Honorabilis-golden yellow, falls striped mahogany.

Imogene Ware-pearly white, edges of petals shaded light blue.

Paranensis-deep purple.

IAVENDULA vera (Lavender). 18 inches, June to October, deep lavender blue.

LOBELIA cardinalis (Cardinal Flower). 2 feet, scarlet, September.

IXSIMACHIA nummularia (Money. wort). 4 inches, June to August, deep blue.

MERTENSIA virginica (Virginia Cowslip). 18 inches, May and June, light blue.

MYYOSOTIS palustris (Forget-me-not) 9 inches, May and June, light blue.

PAEONIA (Herbaceous Peony). 3 feet, May and June. We carry a very large stock of these garden favorites and list below only a few that we think among the best:

Albifiora-late, very double white. 50 cents each; $\$ 4.00$ per 10

Bryant's White-early, very double white.

50 cents each; $\$ 4.00$ per 10

Chas. Gosselyn-late, creamy white. 75 cents each; $\$ 6.00$ per 10

Dorchester-very double late, flesh colored.

50 cents each; $\$ 4.00$ per 10

Couronne d'Or-very double late, yellowish white.

75 cents each; $\$ 6.00$ per 10

Festiva Maxima-very large, early, double, pure white. The best white peony.

75 cents each; $\$ 6.00$ per 10
Floral Treasure-early, double, light pink.

75 cents each; $\$ 6.00$ per 10

Giganthea-very early, choice double pink.

$\$ 1.00$ each; $\$ 8.00$ per 10 .

Golden Harvest-early, double, yellowish white, the nearest approach to a yellow peony.

75 cents each; $\$ 6.00$ per 10

Grandiflora-bright flesh, very large bloom, late.

$\$ 1.00$ each; $\$ 8.00$ per 10 .

La Esperence-fine compact early bloom, light pink.

50 cents each; $\$ 4.00$ per 10

La Tulpe-double white striped rose, midseason.

75 cents each; $\$ 6.00$ per 10

Iivingston-double late, pink splashed carmine.

$\$ 1.00$ each

La Rosarie-pond-lily type, single white showing light stamens.

75 cents each; $\$ 6.00$ per 10

Mad. Brevier-early, a flesh pink fading to white.

50 cents each; $\$ 4.00$ per 10

Mad. Boulanger-double late, delicate pink.

$\$ 1.00$ each

Mad. For'el-very large, double, deep pink.

$\$ 1.00$ each

Ne Plus Ultra-double, midseason, clear flesh pink.

50 cents each; $\$ 4.00$ per 10

Jacqueminot-double late, the red of a Jack rose.

75 cents each; $\$ 6.00$ per 10

Francis Ortegal-very large and double, brilliant crimson, midseason.

50 cents each; $\$ 4.00$ per 10

Fulgida-double, midseason, deep purplish red.

50 cents each; $\$ 4.00$ per 10 .

Felix Crousse-double, late, rosy red. 75 cents each; $\$ 6.00$ per 10

PAPAVER nudicaule (Iceland Poppy) 2 feet, June and July, white, yellow, and scarlet.

P. orientale (Oriental Poppy.) 2 feet, scarlet, June and July.

PHLOX decussata (Perennial Phlox). 2 to 3 feet, June to Ostober.

Unnamed Sorts, 25 cents each, $\$ 1.50$ per 10 . 
PHLOx decussata-Continued.

Named Sorts, 35 cents each, $\$ 2.50$ per 10.

Beranger-white with pink eye.

Bridesmaid-white with crimson eye.

Frauline Bertha Von Lassburg-pure white.

d'Iris-dark purple.

Jeanne d'Arc-late, pure white.

Ia Vague-mauve-pink with red eye.

Le Mahdi-deep purple.

Lothair-salmon pink.

Lamineaux-carmine and rose.

Mm. Bezalson-crimson.

Richard Wallace-white, carmine eye. sir Edward Landseer-crimson.

Sunset-rosy pink.

Pantheon-clear light rose.

P. subulata rosea (Ground or Moss Pink). 6 inches, rosy pink, April and May.

PHYsostegIA virginica (False Dragonhead). 3 feet, July and August, rose.
PIITYCODON grandillorum (Balloon Flower). 2 feet, June and October, blue and white.

RUDBECKIA laciniata II. pl. (Golden Glow). 8 feet, August and September, golden yellow, double.

SEDUM spectabile (Stonecrop). 1 foot, September and October, rose.

STOKESIA cyanea (Cornflower Aster) 2 feet, July to October, sky blue.

VERONICA amethystiana (Speedwell) 2 feet, May and June, blue.

VINCA minor (Periwinkle). Evergreen trailer, blue, April and May.

YUCCA filamentosa (Adam's Needle). Evergreen, 6 feet, Jure and July, very large spikes of creamy white flowers.

3 year plants, 50 cents each; $\$ 3.50$ per 10.
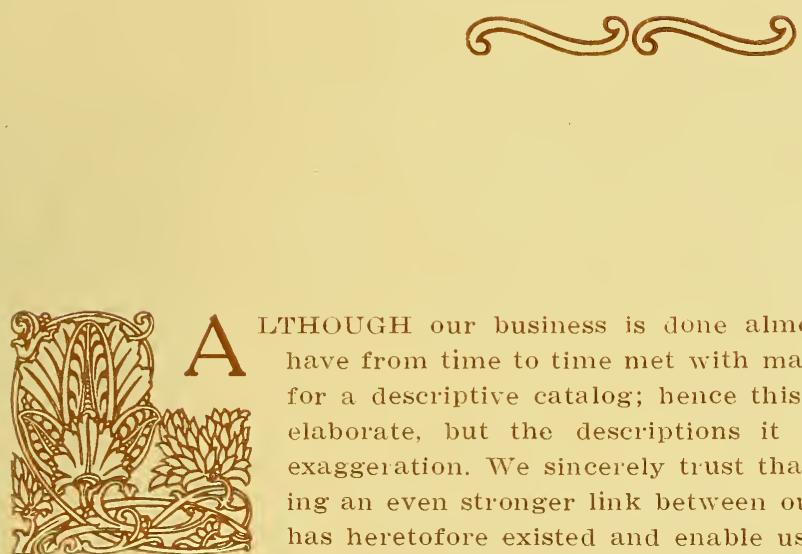

LTHOUGH our business is done almost entirely through agents, we have from time to time met with many requests from our customer's for a descriptive catalog; hence this booklet. It is not very large or elaborate, but the descriptions it contains are true and without exaggeration. We sincerely trust that it will be the means of forming an even stronger link between ourselves and our customers than has heretofore existed and enable us to serve them to a greater advantage.

In making up the lists for this catalog we have confined ourselves to those species and varieties which experience has shown are the best of their kinds for planting under the conditions of soil and climate that are generally found here in the Middle West. We do not list all of the varieties which we carry in stock, and if you do not find here some particular plant in which you are interested, you will do well to write us about it. 


\section{Index to Ornamental Department}

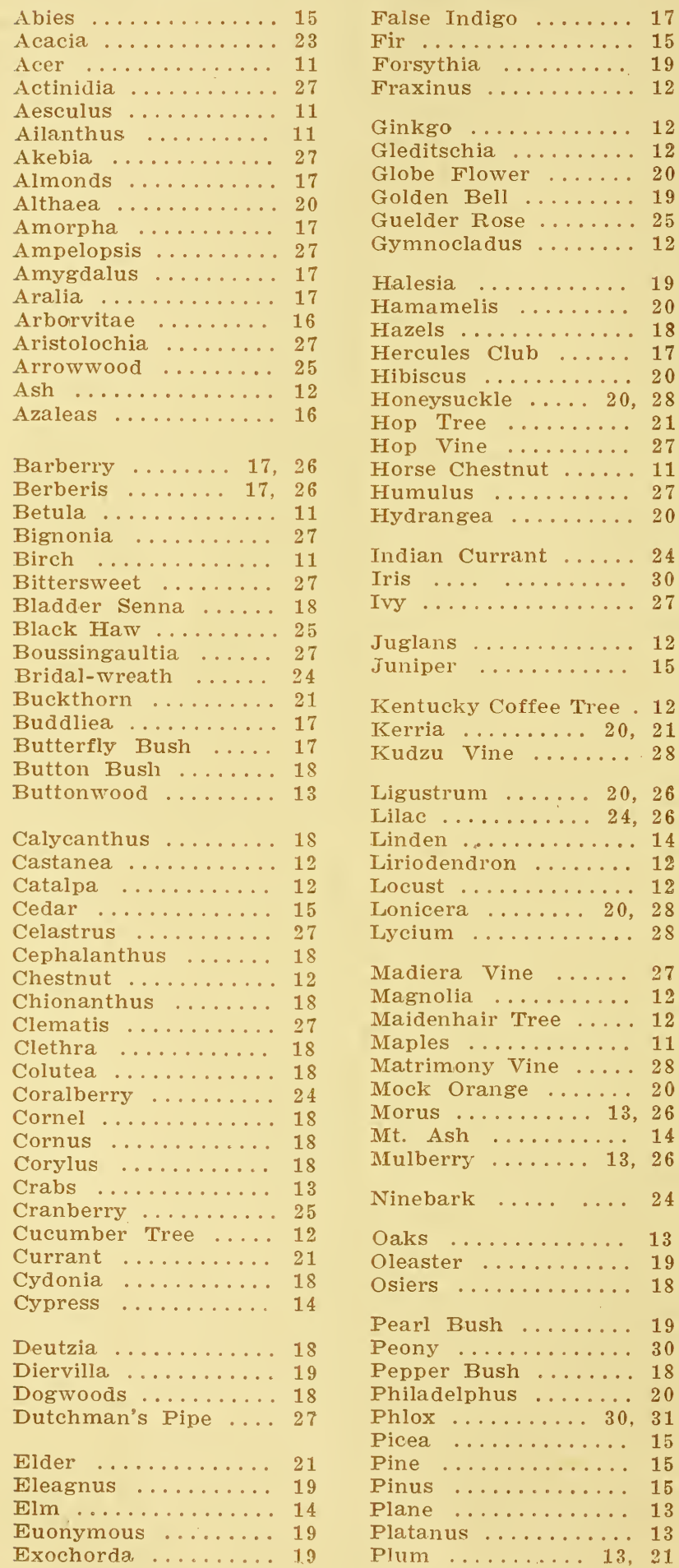

Poplar .......... 13

Populus ......... 13

Privet $\ldots \ldots \ldots 20,26$

Prunus ....... 13, 21

Ptelea .......... 21

Pueraria ........ 28

Purple Fringe ...... 21

Pyrus ......... 13

Quercus ........ 13

Quince ........... 18

Red Cedar ....... 15

Rhamnus. ........ 21

Rhodendron ........ 16

Rhodotypos ........ 21

Rhus ...........21

Ribes ............. 21

Robinia ........ 23

Rosa .......... 23

Rose of Sharon ..... 20

Roses-Garden ..... 22

Roses-Species ..... 23

Salisburia ........ 12

Sambucus ........ 21

Sheepberry ....... 25

Silver Bell ........ 19

Silver Vine ....... 27

Snowball ........ 25

Snowberry ........2 24

Snowdrop Tree ...... 19

Sorbus .......... 14

Spiraea ......... 23

Spruce ......... 15

Sumac .......... 21

Summer Lilac ..... 17

Sweet Bay ........ 12

Sweet Shrub ...... 18

Sycamore ........ 13

Symphoricarpos ..... 24

Syringa $\ldots \ldots 20,24,26$

Tamarix ........ 25

Taxodium ......... 14

Thuya .......... 16

Tilia .......... 14

Tree of Heaven ...... 11

Trumpet Creeper .... 27

Tulip Tree ....... 12

Ulmus $\ldots \ldots \ldots \ldots \ldots 14$

Viburnum ....... 25

Virginia Creeper .... 27

Walnut .......... 12

Wayfaring Tree ..... 25

Waxberry ........ 24

Weigelia ......... 19

White Fringe ....... 1s

White Kerria ...... 21

Witch Hazel ...... 20

Wistaria ......... 28

Woodbine ........ 27

Yucca .......... 31

Yulan ......... 12 


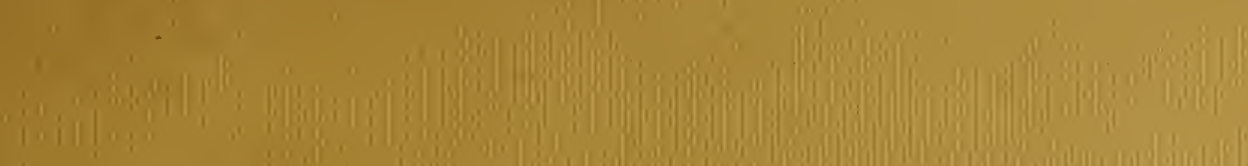

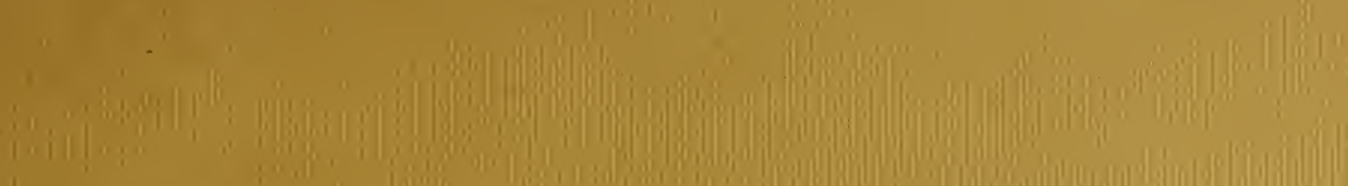

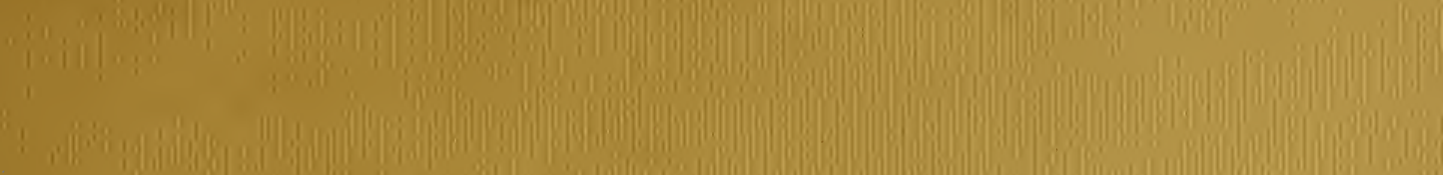

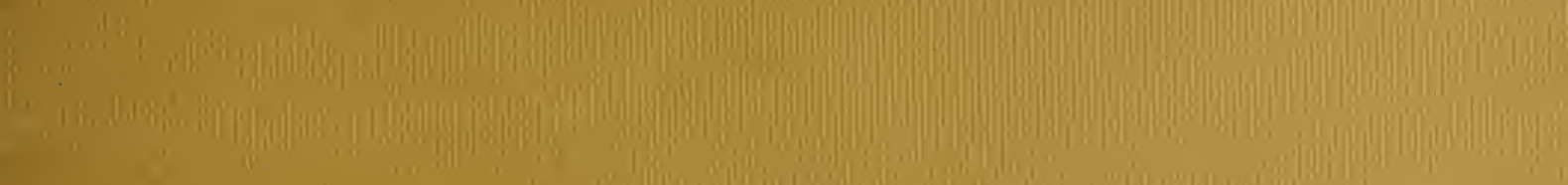
I.

\author{
1:10in
}

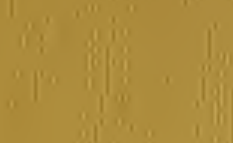

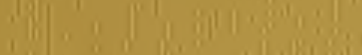

1
1

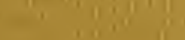

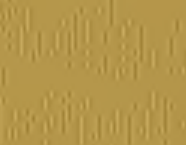

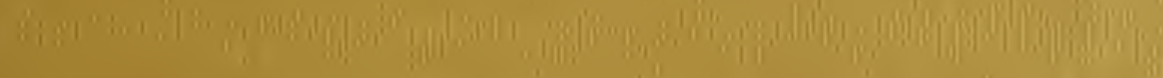

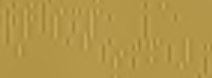
,

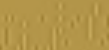
(1)

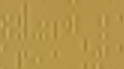

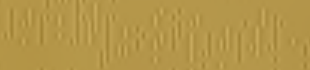

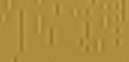

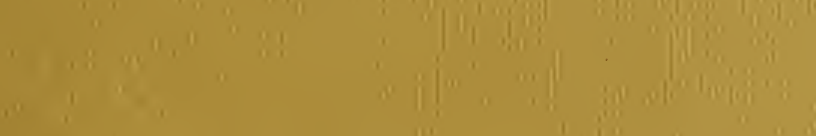

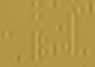

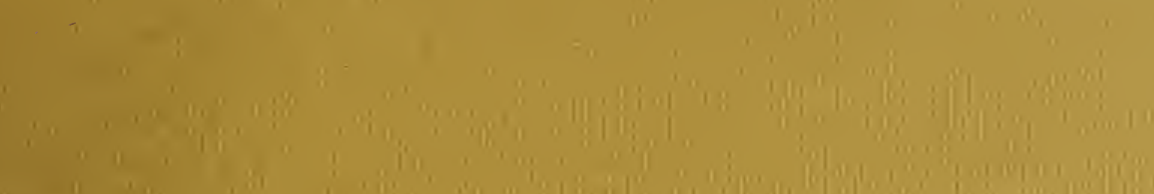

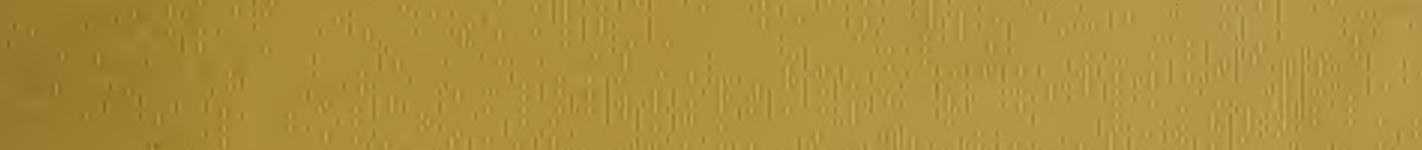

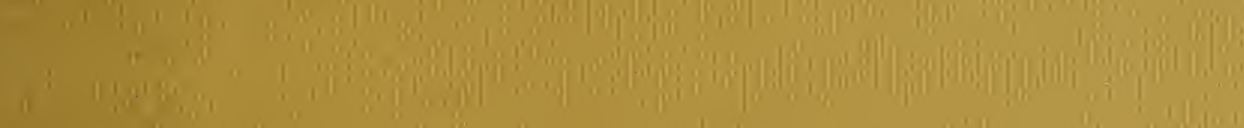
(1) $+\frac{1}{2}$

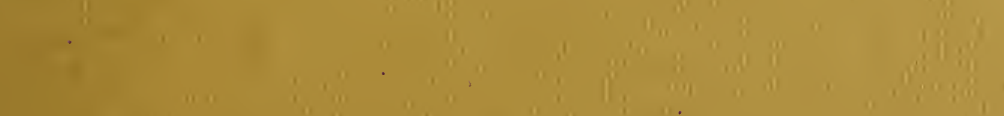

i,

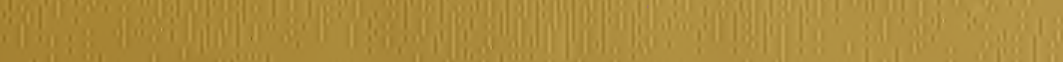

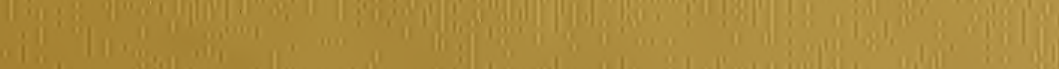

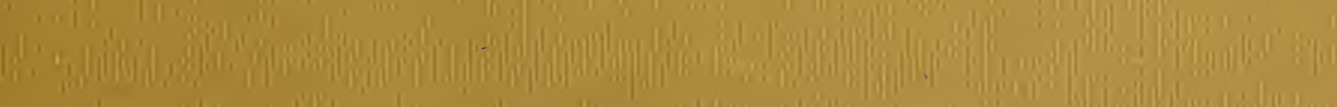
I, 
